\title{
GREEN APPROACH USING WATER MEDIATED DIELS-ALDER REACTION FOR THE SYNTHESIS OF SOME 2-(4-BROMO-1-NAPHTHYL)-3-(ARYL)BICYCLO [2.2.1]HEPT-5-ENE METHANONES AND EVALUATION OF THEIR ANTIMICROBIAL AND ANTIOXIDANT ACTIVITIES
}

\author{
Ganesamoorthy Thirunarayanan \\ Department of Chemistry, Annamalai University, Annamalainagar 608 002, India \\ drgtnarayanan@gmail.com; thirunarayanan.g.10313@annamalaiuniversity.ac.in
}

Some (4-bromo-1-naphthyl)-(3-(substituted phenyl) bicyclo[2.2.1]hept-5-en-2-yl) methyl ketones were synthesized by fly-ash catalyzed environmentally benign Diels-Alder [4+2] cycloaddition reaction of 4-bromo-1-naphthyl chalcones and cyclopentadiene in water medium. In this reaction, the obtained yield was more than $60 \%$. The synthesized methanones were characterized by their physical constants, microanalysis, infrared, nuclear magnetic resonance and mass spectroscopic data. The antibacterial and antifungal activities of these ketones were evaluated by the disc diffusion-zone of inhibition and two-fold serial-dilution-minimum inhibitory concentration of their corresponding bacterial and fungal strains using the Bauer-Kirby method. The antioxidant activities of these methanones were measured using the diphenyl picryl hydrazyl (DPPH) radical scavenging activity method.

Key words: Diels-Alder reaction; 4-bromo-1-naphtyl bicyclo[2.2.1]methanones; antimicrobial activities; antioxidant activity

\section{ЗЕЛЕН ПРИСТАП НА ДИЕЛС-АЛДЕРОВА РЕАКЦИЈА ВО ВОДНА СРЕДИНА ЗА СИНТЕЗА НА НЕКОИ 2-(4-БРОМО-1-НАФТИЛ)-3-АРИЛ БИЦИКЛО[2.2.1]ХЕПТ-5-ЕН МЕТАНОНИ И ПРОЦЕНА НА НИВНАТА АНТИМИКРОБНА И АНТИОКСИДАЦИСКА АКТИВНОСТ}

Некои (4-бромо-1-нафтил)-(3-супституирани фенил) бицикло[2.2.1]хепт-5-ен-2-ил) метил кетони беа синтетизирани во присуство на лебдечки пепел како катализатор во еколошки прифатлива Диелс-Алдерова [4+2] циклоадициска реакција на арил халкони и циклопентадиен во водна средина. Приносот на реакцијата изнесуваше над 60\%. Синтетизираните метанони беа карактеризирани преку нивните физички константи, микроанализа, како и преку инфрацрвени, нуклеарномагнетно-резонантни и масеноспектроскопски податоци. Антибактериските и антифунгицидните активности на добиените кетони беа проценети со активноста на диск дифузивна зонска инхибиција и двократна минимално инхибиторска концентрација при сериско разредување на соодветните видови бактерии и фунги со употреба на методот на Bauer-Kirby. Антиоксидациската активност на овие метанони беше определена со методот на прибирање на радикали со употреба на дифенил пикрил хидразил (DPPH).

Клучни збориви: Диел-Алдерова реакција; 4-бромо-1-нафтил бицикло[2.2.1]метанони; антимикробна активност; антиоксидациска активност

\section{INTRODUCTION}

The environmentally benign water-mediated hetero Diels-Alder [4+2] cyclo-addition reaction is most important for deriving numerous stereospecific, stereoselective, region and enantioselective bicyclo organic substrates [1,2]. Chemists and scientists have paid much more attention to this 
environmentally benign water-mediated reaction for synthesizing methanones [3], cyclic imines [4], cyclohexanone derivatives [5, 6], diones [7], peptide-oligonucleotide conjugates [8], aza compounds [9], bicyclic esters [10], anthracene derivatives [11], cyclic diacids [12], Michael adducts [13], cantharidine-like molecules [14] and melamine peptides [8]. The water mediated environmentally benign hetero Diels-Alder [4+2] cycloaddition reaction was 700 times faster than in nonaqueous phase [3]. Numerous catalysts were employed to perform this Diels-Alder reaction, such as specific and chiral Lewis acids [3, 15], chiral bases [16], chiral amines [5, 6], non-natural $\alpha$ amino acids [17], bimodal catalysts [18], hydrogen bonding interactions [1], chiral silver phosphates [4], Ti(IV) compounds [19], alkaline salts [20], lithium perchlorate [10], pyridyl-modified RNA [11], fly-ash [21-25], carbocations [13], $\mathrm{Cu}(\mathrm{II})$ compounds [2], organo-tungstates with ionicliquids [26], ribozymes [27], low melting carbohydrates [28], and metal-free non-covalent compounds [29]. Fard et al. have studied the solvent effect and performed DFT analysis of acid catalyzed Diels-Alder cycloaddition reaction of 2,5dimethyl furan and maleic anhydride [30]. Kerbs and Laschat reported the isomerization of multiple bonds in tetrahydro-1- $H$-indene-1,5(7a $H)$ dienes by Diels-Alder reaction [7]. The self-Diels-Alder reaction is useful for transformations of $\alpha, \beta$ unsaturated ketones into cyclohexanones [5]. The Diels-Alder products such as cyclic and bicyclic methanones and imines possess significant biological activities [21-25, 31, 32]. Bicyclic ketones are used as starting materials for the synthesis of epoxy ketones [33], higher aromatic ketones, and nitriles [34]. These ketones possess important biological potential such as antimicrobial, antioxidant, insect antifeedant [35-37], cytotoxic [38], cardiotonic, antiarrhythmic, and antishock activities [39], and as fragrance ingredients [40] and anticonvulsants [41]. Recently, Thirunarayanan prepared some bicyclic methanones through a water-mediated Diels-Alder reaction catalyzed by fly-ash: $\mathrm{H}_{2} \mathrm{O}$ catalyst and studied the antimicrobial, antioxidant, and insect antifeedant activities [35-37]. The literature review reveals that there is no information available about the water-mediated fly-ash catalyzed Diels-Alder[4+2] cycloaddition reaction for the synthesis of titled compounds. Hence the author attempted to synthesize of 2-(4-bromo-1-2naphthyl)-3-(substituted phenyl) bicyclo[2.2.1] hepta-5-ene ketones by green chemical water mediated fly-ash catalyzed Diels-Alder[4+2] cycloaddition of $E$-(4-bromo-1-naphthyl)-2-propen-1ones and cyclopentadiene under a cooling condition. The antimicrobial and antioxidant activities of these ketones have been evaluated using disc- diffusion [42] as well as the serial dilution method and diphenyl picryl hydrazyl (DPPH) radical scavenging [37] ability.

\section{EXPERIMENTAL}

\subsection{General}

All chemicals were procured from SigmaAldrich and E-Merck. Fly-ash was collected from Thermal Power Plant-II, Neyveli Lignite Corporation (NLC), Neyveli, Tamil Nadu, India. The melting points of all bicyclo[2.2.1]heptene-2-ylmethanones were determined in open glass capillaries on a Mettler FP51 melting point apparatus and are uncorrected. Infrared (IR) spectra $(\mathrm{KBr}$, $4000-400 \mathrm{~cm}^{-1}$ ) were recorded on a Thermo Scientific Nicolet iS5, (USA) Fourier transform spectrophotometer. The nuclear magnetic resonance (NMR) spectra of selective compounds were recorded by a Bruker AV 400 spectrometer operating at $400 \mathrm{MHz}$ for ${ }^{1} \mathrm{H}$ NMR spectra and $100 \mathrm{MHz}$ for ${ }^{13} \mathrm{C}$ NMR spectra in $\mathrm{CDCl}_{3}$ solvent using tetramethylsilane (TMS) as the internal standard. Electron impact and chemical ionization mode $\mathrm{FAB}^{+}$mass spectra were recorded with a Shimadzu GCMS-TQ8040 model spectrometer. The elemental analysis of all methanones was performed using a Thermo Finnigan Flash EA 1112 model elemental analyzer.

\subsection{Synthesis of 4-bromo-1-naphthyl chalcones}

The substituted styryl 4-bromo-1-naphthylketones were synthesized by a literature method [43].

\subsubsection{General procedure for synthesis} of 4-bromo-1-naphthyl ketone with benzaldehydes

Equimolar quantities of 4-bromo-1-naphthyl ketone $(2 \mathrm{~mol})$, substituted benzaldehydes (2 $\mathrm{mmol})$, and silica-sulfuric acid (1.5 g, equal to 4 mmol of $\mathrm{H}^{+}$) were mixed thoroughly, placed in a $50 \mathrm{ml}$ beaker, and closed with a watch glass (Scheme 1). The mixture was heated in an oven at $80^{\circ} \mathrm{C}$ for $2-3.5 \mathrm{~h}$. After complete conversion of the ketones as monitored by thin layer chromatogram (TLC), the mixture was cooled to room temperature. Dichloromethane $(20-30 \mathrm{ml})$ was added and heated for 3-5 minutes. The reagent was removed by filtration. The filtrate was concentrated and the solid residue was recrystallized from ethanol to obtain the pure products as pale yellow glittering solid. The catalyst was recycled by washing the solid reagent remaining on the filter using ethyl acetate $(20 \mathrm{ml})$ followed by drying in an oven at $50{ }^{\circ} \mathrm{C}$ for $2 \mathrm{~h}$ and it can be reused for another reaction run. 

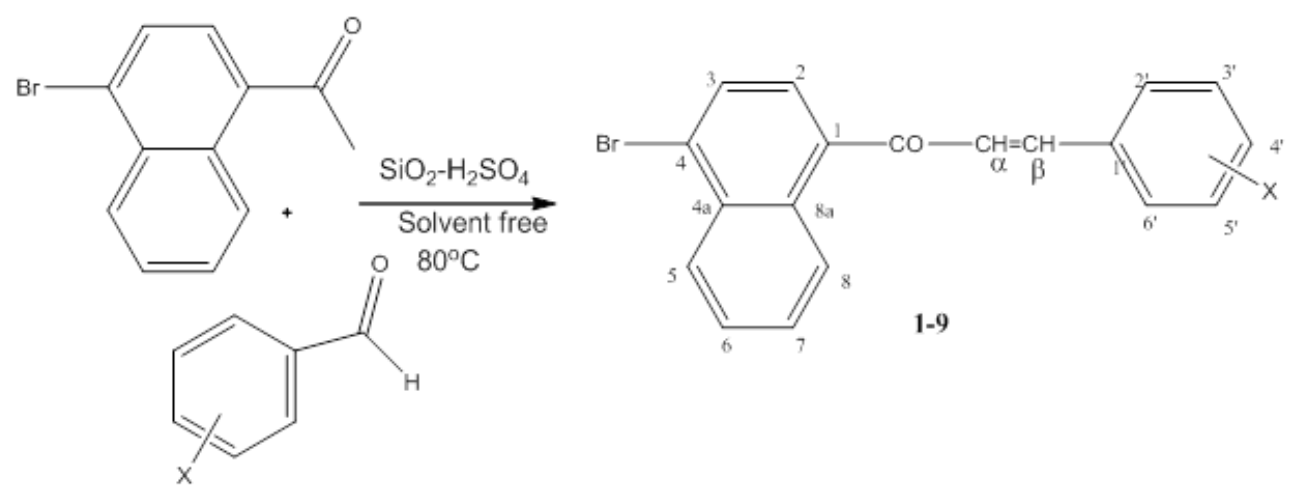

1-9

\begin{tabular}{cccccccccc}
\hline \hline Entry & 1 & 2 & 3 & 4 & 5 & 6 & 7 & 8 & 9 \\
\hline $\mathrm{X}$ & $\mathrm{H}$ & $3-\mathrm{NH}_{2}$ & $3-\mathrm{Br}$ & $4-\mathrm{Cl}$ & $4-\mathrm{N}\left(\mathrm{CH}_{3}\right)_{2}$ & $4-\mathrm{OH}$ & $4-\mathrm{OCH}_{3}$ & $4-\mathrm{CH}_{3}$ & $4-\mathrm{NO}_{2}$ \\
\hline \hline
\end{tabular}

Scheme 1. Synthesis of 4-bromo-1-naphthyl chalcones

The infrared carbonyl stretching frequencies of $s$-cis and s-trans conformers are assigned. Similarly the nuclear magnetic resonance chemical shifts $(\delta, \mathrm{ppm})$ of ethylene $\alpha, \beta$ protons and carbons are assigned. The characterization data of all chalcones are summarized as follows.

(2E)-1-(4-bromo-1-naphthyl)-3-phenyl-2-propen1-one (1). Yield: $96 \%$, m.p. $103-104{ }^{\circ} \mathrm{C}$; IR (KBr, $\left.\mathrm{cm}^{-1}\right): v=1687(\mathrm{CO}$ s-cis $), 1657(\mathrm{CO}$ s-trans $), 984$ $(\mathrm{CH}=\mathrm{CH}) .{ }^{1} \mathrm{H}$ NMR $\left(\mathrm{CDCl}_{3}, \mathrm{ppm}\right): \delta=8.249$ $(\mathrm{d}, 1 \mathrm{H} \alpha), 8.364$ (d,1H $\beta), 7.192-7.864$ (m, 11H Ar$\mathrm{H}) .{ }^{13} \mathrm{C}$ NMR $\left(\mathrm{CDCl}_{3}, \mathrm{ppm}\right): \delta=122.846\left(\mathrm{C}_{\alpha}\right)$ $144.762\left(\mathrm{C}_{\beta}\right), 192.092(\mathrm{CO}), 136.954\left(\mathrm{C}_{1}\right), 129.816$ $\left(\mathrm{C}_{2}\right), 129.907\left(\mathrm{C}_{3}\right), 128.218\left(\mathrm{C}_{4}\right), 129.907\left(\mathrm{C}_{5}\right)$, $126.437\left(\mathrm{C}_{6}\right), 127.300\left(\mathrm{C}_{7}\right), 125.816\left(\mathrm{C}_{8}\right), 133.00$ $\left(\mathrm{C}_{4 \mathrm{a}}\right), \quad 133.737 \quad\left(\mathrm{C}_{8 \mathrm{a}}\right), \quad 137.201 \quad\left(\mathrm{C}_{1}{ }^{\prime}\right), 126.003$ $\left(\mathrm{C}_{2}^{\prime}, \mathrm{C}_{6}{ }^{\prime}\right), 128.665\left(\mathrm{C}_{3}^{\prime}, \mathrm{C}_{5}{ }^{\prime}\right), 138.216\left(\mathrm{C}_{4}{ }^{\prime}\right)$. Analysis. Calcd. for $\mathrm{C}_{19} \mathrm{H}_{13} \mathrm{OBr}$ (337.20): C, 67.67; H, 3.89. Found: C, 67.59; H 3.82(\%).

\section{(2E)-1-(4-bromo-1-naphthyl)-3-(3-aminophenyl)-}

2-propen-1-one (2). Yield: $92 \%$, m.p. $72-73{ }^{\circ} \mathrm{C}$; IR $\left(\mathrm{KBr}, \mathrm{cm}^{-1}\right): v=1677(\mathrm{CO}$ s-cis), $1644(\mathrm{CO}$ s-trans), $996(\mathrm{CH}=\mathrm{CH}), 3623\left(-\mathrm{NH}_{2}\right) .{ }^{1} \mathrm{H}$ NMR $\left(\mathrm{CDCl}_{3}\right.$, ppm): $\delta=8.245(\mathrm{~d}, 1 \mathrm{H} \quad \alpha), 8.310(\mathrm{~d}, 1 \mathrm{H} \quad \beta)$, 7.311-8.513 (m, 10H Ar-H), 4.623 (s, $\left.2 \mathrm{H}-\mathrm{NH}_{2}\right) .{ }^{13} \mathrm{C}$ $\operatorname{NMR}\left(\mathrm{CDCl}_{3}, \mathrm{ppm}\right): \delta=120.201\left(\mathrm{C}_{\alpha}\right) 143.344\left(\mathrm{C}_{\beta}\right)$, $192.402(\mathrm{CO}), 136.421\left(\mathrm{C}_{1}\right), 126.000\left(\mathrm{C}_{2}\right), 128.980$ $\left(\mathrm{C}_{3}\right), \quad 127.410\left(\mathrm{C}_{4}\right), 128.418\left(\mathrm{C}_{5}\right), 126.317 \quad\left(\mathrm{C}_{6}\right)$, $128.300\left(\mathrm{C}_{7}\right), 127.816\left(\mathrm{C}_{8}\right), 133.744\left(\mathrm{C}_{4 \mathrm{a}}\right), 133.740$ $\left(\mathrm{C}_{8 \mathrm{a}}\right), 132.452\left(\mathrm{C}_{1}{ }^{\prime}\right), 113.203\left(\mathrm{C}_{2}{ }^{\prime}\right), 147.209\left(\mathrm{C}_{3}{ }^{\prime}\right)$, $115.728\left(\mathrm{C}_{4}{ }^{\prime}\right), 130.174\left(\mathrm{C}_{5}{ }^{\prime}\right), 115.728\left(\mathrm{C}_{6}{ }^{\prime}\right)$. Analysis. Calcd. for $\mathrm{C}_{19} \mathrm{H}_{14} \mathrm{BrNO}$ (337.20): C, 64.79; $\mathrm{H}, 4.01$; N, 3.98. Found: C, 64.67: H, 3.98; N, 3.69(\%).

(2E)-1-(4-bromo-1-naphthyl)-3-(3-bromophenyl)-2propen-1-one (3). Yield: $95 \%$, m.p. $107-108{ }^{\circ} \mathrm{C}$; IR
$\left(\mathrm{KBr}, \mathrm{cm}^{-1}\right): v=1681(\mathrm{CO} s$-cis), $1658(\mathrm{CO}$ s-trans), $1025(\mathrm{CH}=\mathrm{CH}) .{ }^{1} \mathrm{H} \mathrm{NMR}\left(\mathrm{CDCl}_{3}, \mathrm{ppm}\right): \delta=8.309$ $(\mathrm{d}, 1 \mathrm{H} \alpha), 8.335(\mathrm{~d}, 1 \mathrm{H} \beta), 7.515-8.052$ (m, 10H Ar$\mathrm{H}) .{ }^{13} \mathrm{C}$ NMR $\left(\mathrm{CDCl}_{3}, \mathrm{ppm}\right): \delta=121.640\left(\mathrm{C}_{\alpha}\right)$ $142.030\left(\mathrm{C}_{\beta}\right), 192.667(\mathrm{CO}), 137.020\left(\mathrm{C}_{1}\right), 127.736$ $\left(\mathrm{C}_{2}\right), \quad 129.480 \quad\left(\mathrm{C}_{3}\right), \quad 123.280 \quad\left(\mathrm{C}_{4}\right), 128.750 \quad\left(\mathrm{C}_{5}\right)$, $126.737\left(\mathrm{C}_{6}\right), 128.098\left(\mathrm{C}_{7}\right), 134.690\left(\mathrm{C}_{8}\right), 134.989$ $\left(\mathrm{C}_{4 \mathrm{a}}\right), 130.294\left(\mathrm{C}_{8 \mathrm{a}}\right), 140.437\left(\mathrm{C}_{1}{ }^{\prime}\right), 129.633\left(\mathrm{C}_{2}{ }^{\prime}\right)$, $128.280\left(\mathrm{C}_{3}{ }^{\prime}\right), 131.341\left(\mathrm{C}_{4}{ }^{\prime}\right), 130.294\left(\mathrm{C}_{5}^{\prime}\right), 124.995$ $\left(\mathrm{C}_{6}{ }^{\prime}\right)$. Analysis. Calcd. for $\mathrm{C}_{19} \mathrm{H}_{12} \mathrm{Br}_{2} \mathrm{O}$ (416.10): $\mathrm{C}$, 54.84; H, 2.91. Found: C, 54.79; H, 2.83(\%).

(2E)-1-(4-bromo-1-naphthyl)-3-(4-chlorophenyl)-2 -propen-1-one (4) Yield: $96 \%$, m.p. $100-101{ }^{\circ} \mathrm{C}$; IR $\left(\mathrm{KBr}, \mathrm{cm}^{-1}\right): v=1679(\mathrm{CO} s$-cis), 1652 (CO s-trans), $1029(\mathrm{CH}=\mathrm{CH}) .{ }^{1} \mathrm{H}$ NMR $\left(\mathrm{CDCl}_{3}, \mathrm{ppm}\right): \delta=8.300$ $(\mathrm{d}, 1 \mathrm{H} \alpha), 8.322(\mathrm{~d}, 1 \mathrm{H} \beta), 7.388-7.819$ (m, 10H Ar$\mathrm{H}) .{ }^{13} \mathrm{C}$ NMR $\left(\mathrm{CDCl}_{3}, \mathrm{ppm}\right): \delta=121.306\left(\mathrm{C}_{\alpha}\right)$ $143.725\left(\mathrm{C}_{\beta}\right), 186.601(\mathrm{CO}), 136.858\left(\mathrm{C}_{1}\right), 129.665$ $\left(\mathrm{C}_{2}\right), \quad 128.770 \quad\left(\mathrm{C}_{3}\right), \quad 126.860 \quad\left(\mathrm{C}_{4}\right), 128.250 \quad\left(\mathrm{C}_{5}\right)$, $126.060\left(\mathrm{C}_{6}\right), 132.894\left(\mathrm{C}_{7}\right), 121.306\left(\mathrm{C}_{8}\right), 130.330$ $\left(\mathrm{C}_{4 \mathrm{a}}\right), 130.772\left(\mathrm{C}_{8 \mathrm{a}}\right), 136.857\left(\mathrm{C}_{1}{ }^{\prime}\right), 127.956\left(\mathrm{C}_{2}{ }^{\prime}, \mathrm{C}_{6}{ }^{\prime}\right)$, $129.330\left(\mathrm{C}_{3}{ }^{\prime}, \mathrm{C}_{5}{ }^{\prime}\right), 136.888\left(\mathrm{C}_{4}{ }^{\prime}\right)$. Analysis. Calcd. for $\mathrm{C}_{19} \mathrm{H}_{12} \mathrm{BrClO}$ (371.05): $\mathrm{C}, 61.40 ; \mathrm{H}, 3.25$. Found: $\mathrm{C}$, $61.32 ; \mathrm{H}, 3.22(\%)$.

(2E)-1-(4-bromo-1-naphthyl)-3-(4-dimethylaminophenyl)-2-propen-1-one (5). Yield: 93\%, m.p. 118-119 ${ }^{\circ} \mathrm{C}$; IR $\left(\mathrm{KBr}, \mathrm{cm}^{-1}\right): v=1672$ (CO s-cis), 1631 (CO s-trans), $976(\mathrm{CH}=\mathrm{CH}), 3576\left(-\mathrm{NH}_{2}\right) .{ }^{1} \mathrm{H}$ NMR $\left(\mathrm{CDCl}_{3}, \mathrm{ppm}\right): \delta=8.122(\mathrm{~d}, 1 \mathrm{H} \alpha), 8.199(\mathrm{~d}, 1 \mathrm{H}$ $\beta), 7.636-8.319(\mathrm{~m}, 10 \mathrm{H}$ Ar-H), $2.88(\mathrm{~s}, 6 \mathrm{H}-$ $\left.\left(\mathrm{CH}_{3}\right)_{2}\right) .{ }^{13} \mathrm{C} \mathrm{NMR}\left(\mathrm{CDCl}_{3}, \mathrm{ppm}\right): \delta=118.800\left(\mathrm{C}_{\alpha}\right)$ $141.300\left(\mathrm{C}_{\beta}\right), 190.200(\mathrm{CO}), 42.840\left(\mathrm{CH}_{3}\right), 135.00$ $\left(\mathrm{C}_{1}\right), 129.724\left(\mathrm{C}_{2}\right), 127.994\left(\mathrm{C}_{3}\right), 129.091\left(\mathrm{C}_{4}\right)$, $130.144\left(\mathrm{C}_{5}\right), 128.947\left(\mathrm{C}_{6}\right), 128.527\left(\mathrm{C}_{7}\right), 124.720$ $\left(\mathrm{C}_{8}\right), 130.149\left(\mathrm{C}_{4 \mathrm{a}}\right), 129.091\left(\mathrm{C}_{8 \mathrm{a}}\right), 124.720\left(\mathrm{C}_{1}{ }^{\prime}\right)$, $126.920\left(\mathrm{C}_{2}^{\prime}, \mathrm{C}_{6}{ }^{\prime}\right), 114.417\left(\mathrm{C}_{3}^{\prime}, \mathrm{C}_{5}{ }^{\prime}\right), 152.470\left(\mathrm{C}_{4}{ }^{\prime}\right)$. 
Analysis. Calcd. for $\mathrm{C}_{21} \mathrm{H}_{18} \mathrm{BrNO}$ (380.27): C, 66.33; H, 4.77; N, 3.68. Found: C, 66.34; H, 4.67; $\mathrm{N}, 3.64(\%)$.

(2E)-1-(4-bromo-1-naphthyl)-3-(4-hydroxyphenyl)2-propen-1-one (6). Yield: $91 \%$, m.p. $97-98{ }^{\circ} \mathrm{C}$; IR $\left(\mathrm{KBr}, \mathrm{cm}^{-1}\right): v=1671(\mathrm{CO} s$-cis $), 1635$ (CO strans $), 1015(\mathrm{CH}=\mathrm{CH}), 3565(-\mathrm{OH}) .{ }^{1} \mathrm{H}$ NMR $\left(\mathrm{CDCl}_{3}, \mathrm{ppm}\right): \delta=8.184(\mathrm{~d}, 1 \mathrm{H} \alpha), 8.204(\mathrm{~d}, 1 \mathrm{H} \beta)$, 7.688-7.843 (m, 10H Ar-H), $4.752(\mathrm{~s}, 1 \mathrm{H}-\mathrm{OH})$. ${ }^{13} \mathrm{C} \mathrm{NMR}\left(\mathrm{CDCl}_{3}, \mathrm{ppm}\right): \delta=119.716\left(\mathrm{C}_{\alpha}\right) 143.560$ $\left(\mathrm{C}_{\beta}\right), 191.200(\mathrm{CO}), 134.521\left(\mathrm{C}_{1}\right), 128.533\left(\mathrm{C}_{2}\right)$, $130.055\left(\mathrm{C}_{3}\right), 128.533\left(\mathrm{C}_{4}\right), 130.299\left(\mathrm{C}_{5}\right), 128.340$ $\left(\mathrm{C}_{6}\right), 132.144\left(\mathrm{C}_{7}\right), 124.924\left(\mathrm{C}_{8}\right), 132.144\left(\mathrm{C}_{4 \mathrm{a}}\right)$, $130.022\left(\mathrm{C}_{8 \mathrm{a}}\right), 130.032\left(\mathrm{C}_{1}{ }^{\prime}\right), 129.461\left(\mathrm{C}_{2}{ }^{\prime}, \mathrm{C}_{6}{ }^{\prime}\right)$, $116.992\left(\mathrm{C}_{3}{ }^{\prime}, \mathrm{C}_{5}{ }^{\prime}\right), 157.924\left(\mathrm{C}_{4}{ }^{\prime}\right)$. Analysis. Calcd. for $\mathrm{C}_{19} \mathrm{H}_{13} \mathrm{BrO}_{2}(353.20)$ : $\mathrm{C}, 64.61 ; \mathrm{H}, 3.71$. Found: $\mathrm{C}, 64.59 ; \mathrm{H}, 3.69(\%)$.

(2E)-1-(4-bromo-1-naphthyl)-3-(4-methoxyphenyl)2-propen-1-one (7). Yield: $96 \%$, m.p. $123-124{ }^{\circ} \mathrm{C}$; IR $\left(\mathrm{KBr}, \mathrm{cm}^{-1}\right): v=1685$ (CO s-cis), $1641(\mathrm{CO} \mathrm{s}$ trans $), 1024(\mathrm{CH}=\mathrm{CH}) .{ }^{1} \mathrm{H}$ NMR $\left(\mathrm{CDCl}_{3}, \mathrm{ppm}\right): \delta=$ $8.213(\mathrm{~d}, 1 \mathrm{H} \alpha), 8.337(\mathrm{~d}, 1 \mathrm{H} \beta), 7.053-7.824(\mathrm{~m}$, $10 \mathrm{H} \mathrm{Ar}-\mathrm{H}) 4.132\left(\mathrm{~s}, 3 \mathrm{H}-\mathrm{OCH}_{3}\right) .{ }^{13} \mathrm{C} \mathrm{NMR}\left(\mathrm{CDCl}_{3}\right.$, ppm): $\delta=121.440\left(\mathrm{C}_{\alpha}\right) 142.619\left(\mathrm{C}_{\beta}\right), 193.900(\mathrm{CO})$, $53.810 \quad\left(-\mathrm{OCH}_{3}\right) \quad 138.207 \quad\left(\mathrm{C}_{1}\right), \quad 129.905 \quad\left(\mathrm{C}_{2}\right)$, $128.850\left(\mathrm{C}_{3}\right), 121.957\left(\mathrm{C}_{4}\right), 128.850\left(\mathrm{C}_{5}\right), 126.701$ $\left(\mathrm{C}_{6}\right), 127.102\left(\mathrm{C}_{7}\right), 128.170\left(\mathrm{C}_{8}\right), 132.220\left(\mathrm{C}_{4 \mathrm{a}}\right)$, $130.599\left(\mathrm{C}_{8 \mathrm{a}}\right), 131.753\left(\mathrm{C}_{1}{ }^{\prime}\right), 127.102\left(\mathrm{C}_{2}{ }^{\prime}, \mathrm{C}_{6}{ }^{\prime}\right)$, $116.992\left(\mathrm{C}_{3}{ }^{\prime}, \mathrm{C}_{5}{ }^{\prime}\right), 163.446\left(\mathrm{C}_{4}{ }^{\prime}\right)$. Analysis. Calcd. for $\mathrm{C}_{20} \mathrm{H}_{15} \mathrm{BrO}_{2}$ (367.23): $\mathrm{C}, 65.40 ; \mathrm{H}, 4.12$. Found: C, 65.39; H, 4.00(\%).

(2E)-1-(4-bromo-1-naphthyl)-3-(4-methylphenyl)2-propen-1-one (8). Yield: $94 \%$, m.p. $95-96{ }^{\circ} \mathrm{C}$; $\operatorname{IR}\left(\mathrm{KBr}, \mathrm{cm}^{-1}\right): v=1676(\mathrm{CO}$ s-cis $), 1642(\mathrm{CO} s$ trans), $993(\mathrm{CH}=\mathrm{CH}) .{ }^{1} \mathrm{H} \mathrm{NMR}\left(\mathrm{CDCl}_{3}, \mathrm{ppm}\right): \delta$ $=8.255(\mathrm{~d}, 1 \mathrm{H} \alpha), 8.363(\mathrm{~d}, 1 \mathrm{H} \beta), 7.211-7.846(\mathrm{~m}$, $10 \mathrm{H} \mathrm{Ar}-\mathrm{H}) 2.574\left(\mathrm{~s}, 3 \mathrm{H}-\mathrm{CH}_{3}\right) .{ }^{13} \mathrm{C}$ NMR $\left(\mathrm{CDCl}_{3}\right.$, ppm): $\delta=120.481\left(\mathrm{C}_{\alpha}\right), 143.159\left(\mathrm{C}_{\beta}\right), 191.990$ (CO), $25.300\left(-\mathrm{CH}_{3}\right) 137.252\left(\mathrm{C}_{1}\right), 129.791\left(\mathrm{C}_{2}\right)$, $131.095\left(\mathrm{C}_{3}\right), 128.804\left(\mathrm{C}_{4}\right), 130.214\left(\mathrm{C}_{5}\right), 128.610$ $\left(\mathrm{C}_{6}\right), 132.294\left(\mathrm{C}_{7}\right), 122.610\left(\mathrm{C}_{8}\right), 130.214\left(\mathrm{C}_{4 \mathrm{a}}\right)$, $130.218\left(\mathrm{C}_{8 \mathrm{a}}\right), 137.252\left(\mathrm{C}_{1}{ }^{\prime}\right), 126.435\left(\mathrm{C}_{2}{ }^{\prime}, \mathrm{C}_{6}{ }^{\prime}\right)$, $129.791\left(\mathrm{C}_{3}{ }^{\prime}, \mathrm{C}_{5}{ }^{\prime}\right), 137.252\left(\mathrm{C}_{4}{ }^{\prime}\right)$. Analysis. Calcd. for $\mathrm{C}_{20} \mathrm{H}_{15} \mathrm{BrO}$ (351.23): $\mathrm{C}, 68.39 ; \mathrm{H}, 4.30$. Found: C, 68.34: H, 3.99(\%).

(2E)-1-(4-bromo-1-naphthyl)-3-(4-nitrophenyl)-2 -propen-1-one (9). Yield: $94 \%$, m. p. $116-117{ }^{\circ} \mathrm{C}$; IR $\left(\mathrm{KBr}, \mathrm{cm}^{-1}\right): v=1684$ (CO s-cis), 1672 (CO strans), $1016(\mathrm{CH}=\mathrm{CH}) .{ }^{1} \mathrm{H} \mathrm{NMR}\left(\mathrm{CDCl}_{3}, \mathrm{ppm}\right): \delta=$ $8.334(\mathrm{~d}, 1 \mathrm{H} \alpha), 8.401(\mathrm{~d}, 1 \mathrm{H} \beta), 7.349-8.135(\mathrm{~m}, 10 \mathrm{H}$ $\mathrm{Ar}-\mathrm{H}) .{ }^{13} \mathrm{C}$ NMR $\left(\mathrm{CDCl}_{3}, \mathrm{ppm}\right): \delta=123.433\left(\mathrm{C}_{\alpha}\right)$ $145.183\left(\mathrm{C}_{\beta}\right), 193.552(\mathrm{CO}), 139.103\left(\mathrm{C}_{1}\right), 129.580$ $\left(\mathrm{C}_{2}\right), 132.103 \quad\left(\mathrm{C}_{3}\right), 128.546 \quad\left(\mathrm{C}_{4}\right), 129.580\left(\mathrm{C}_{5}\right)$, $127.204\left(\mathrm{C}_{6}\right), 127.204\left(\mathrm{C}_{7}\right), 129.580\left(\mathrm{C}_{8}\right), 135.920$ $\left(\mathrm{C}_{4 \mathrm{a}}\right), 132.103\left(\mathrm{C}_{8 \mathrm{a}}\right), 142.466\left(\mathrm{C}_{1}{ }^{\prime}\right), 127.598\left(\mathrm{C}_{2}{ }^{\prime}, \mathrm{C}_{6}{ }^{\prime}\right)$, $115.716\left(\mathrm{C}_{3}{ }^{\prime}, \mathrm{C}_{5}{ }^{\prime}\right), 148.499\left(\mathrm{C}_{4}{ }^{\prime}\right)$. Analysis. Calcd. for $\mathrm{C}_{19} \mathrm{H}_{12} \mathrm{BrNO}_{3}$ (382.20): C, 59.71; H, 3.16; N, 3.66. Found: C, 59.68; H, 3.11; N, 3.58(\%).

\subsection{General procedure for synthesis} of (4-bromo-1-naphthyl)-(3-(substituted phenyl)bicyclo[2.2.1]hept-5-en-2-yl)methanones

In a $100 \mathrm{ml}$ conical flask, $2 \mathrm{mmol}$ of $4-$ bromo-1-naphthyl chalcones $5 \mathrm{ml}$ of ethanol, cyclopentadiene ( $2 \mathrm{mmol}$ ), and $0.4 \mathrm{~g}$ of fly-ash in 20 $\mathrm{ml}$ of water were taken and stirred for $6 \mathrm{~h}$ in an ice bath at a temperature of $0-4{ }^{\circ} \mathrm{C}$ (Scheme 2) and the reaction mixture was kept overnight.
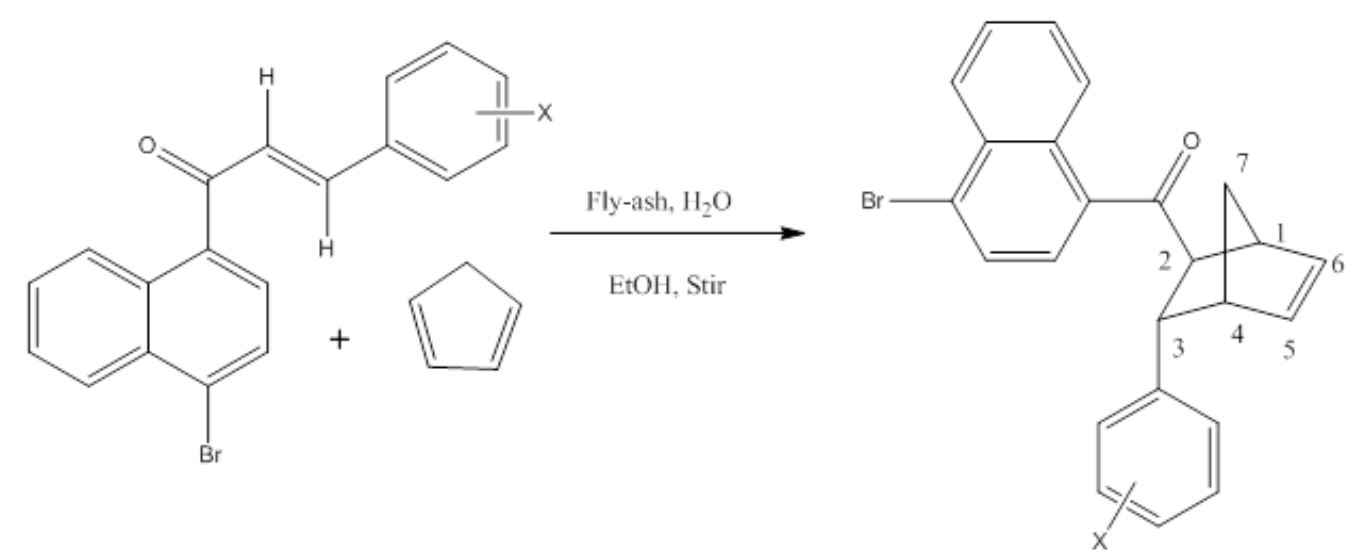

\begin{tabular}{cccccccccc}
\hline \hline Entry & 10 & 11 & 12 & 13 & 14 & 15 & 16 & 17 & 18 \\
\hline $\mathrm{X}$ & $\mathrm{H}$ & $3-\mathrm{NH}_{2}$ & $3-\mathrm{Br}$ & $4-\mathrm{Cl}$ & $4-\mathrm{N}_{\left(\mathrm{CH}_{3}\right)_{2}}$ & $4-\mathrm{OH}$ & $4-\mathrm{OCH}_{3}$ & $4-\mathrm{CH}_{3}$ & $4-\mathrm{NO}_{2}$ \\
\hline \hline
\end{tabular}

Scheme 2. Synthesis of (4-bromo-1-naphthyl)(3-(substituted phenyl)bicyclo[2.2.1] hept-5-en-2-yl) methanones 
The completion of the reaction was monitored by thin layer chromatogram. Dichloromethane $(10 \mathrm{ml})$ was added and the extract was separated by filtration. The filtrate was washed with water, and brine $(10 \mathrm{ml})$, dried over anhydrous $\mathrm{Na}_{2} \mathrm{SO}_{4}$ and concentrated to give the solid product. The crude product was further purified by recrystallization with ethanol. The catalyst was washed with $5 \mathrm{ml}$ of ethyl acetate and dried in a hot air oven at $110^{\circ} \mathrm{C}$ for $3 \mathrm{~h}$. Then this catalyst was reused for further reaction runs.

\subsection{Measurement of antimicrobial activity}

The antimicrobial activities such as the antibacterial and antifungal activities, of prepared bicyclo[2.2.1]heptene-2-yl-methanones were evaluated using the disc-diffusion and serial dilution methods. The prepared bicyclo[2.2.1] heptene-2-ylmethanones subjected to evaluate the antimicrobial activities by measuring the zone of inhibition against bacterial and fungal strains. Three Grampositive pathogenic strains (Staphylococcus aureus, S. typhi, and Enterococcus faecalis) and three Gram-negative strains (Escherichia coli, Pseudomonas aeruginosa and Klebsiella pneumoniae) were applied for evaluation of antimicrobial activities. The Bauer-Kirby [36] disc diffusion technique was adopted with a concentration of $250 \mu \mathrm{g} / \mathrm{ml}$ of with ampicillin and miconazole as standards.

\subsubsection{Measurement of antibacterial sensitivity by disc diffusion method}

The Bauer-Kirby [36] disc diffusion technique was adopted for antibacterial sensitivity assay measurements of all compounds. About $0.5 \mathrm{ml}$ of the bacterial test compounds was spread uniformly over solidified Mueller-Hinton agar. Discs about $5 \mathrm{~mm}$ in diameter, made from Whatman No. 1 filter paper, were placed on the medium with potential inhibitor solution. The plates were incubated for $24 \mathrm{~h}$ at $37^{\circ} \mathrm{C}$ upside down to prevent the collection of water droplets over the medium. Then the plates were examined and the diameters $(\mathrm{mm})$ of zone of inhibition were measured. The results were recorded in triplicate.

\subsubsection{Measurement of antifungal sensitivity by disc diffusion method}

The Bauer-Kirby [36] disc diffusion technique was used for the measurement of antifungal activity of synthesized methanones. Sterilized potato dextrose agar medium was added to the Petri plates containing $1 \mathrm{ml}$ of fungal strains. Uniform spreading of the agar on the plates was performed by means of clockwise and anti-clockwise rotation of the discs. The test sample was made by dissolving $15 \mathrm{mg}$ of the methanones in $1 \mathrm{ml}$ of dimethylsulfoxide (DMSO) solvent and applying it on the discs. This medium was solidified by incubation for 24 or $72 \mathrm{~h}$ at 25 or $28^{\circ} \mathrm{C}$. Then these plates were examined for the evaluation of antifungal activity by measuring the diameters $(\mathrm{mm})$ of the zones of inhibition. Measurement results were recorded in triplicate.

\subsection{Antioxidant activity by radical scavenging method}

The diphenyl picryl hydrazyl (DPPH) radical scavenging activity technique [35] was used for the measurement of the antioxidant activity of all prepared methanones. About $20 \mathrm{ml}$ of sodium acetate buffer solution was prepared by dissolving $1.64 \mathrm{~g}$ of sodium acetate in $15 \mathrm{ml}$ of water and $150 \mu \mathrm{l}$ of acetic acid, and the final volume was adjusted to $20 \mathrm{ml}$ of water. About $50 \mathrm{ml}$ of $0.2 \mathrm{mmol}$ diphenyl picryl hydrazyl (DPPH) solution was prepared by dissolving $3.9 \mathrm{~g}$ of diphenyl picryl hydrazyl (DPPH) in 50 $\mathrm{ml}$ of ethanol. About $10 \mathrm{ml}$ of $\alpha$-tocopherol solution was prepared by dissolving $1 \mathrm{mg}$ of $\alpha$-tocopherol in $10 \mathrm{ml}$ of ethanol. About $1.0 \mathrm{ml}$ of buffer solution was mixed with $0.5 \mathrm{ml}$ of diphenyl picryl hydrazyl (DPPH) solution in the test tubes and arranged serially. The test solution and $\alpha$-tocopherol solution were added to the test tubes and kept aside for 30 minutes at room temperature. The absorbance was measured on a UV-vis spectrophotometer (Shimad$\mathrm{zu}-1650$ ) at $517 \mathrm{~nm}$. A mixture of sodium acetate buffer and ethanol was used as the reference. The plot was made with the quantity of the compound versus absorption and the $\mathrm{IC}_{50}$ values were determined. The antioxidant activity was expressed in terms of the $\mathrm{IC}_{50}(\mu \mathrm{g} / \mathrm{ml}$, concentration required to inhibit diphenyl picryl hydrazyl (DPPH) radical formation by $50 \%$ ). $\alpha$-Tocopherol was taken as a positive control. The radical scavenging activity was calculated as:

DPPH radical scavenging activity $(\%$ inhibition $)=$

$\frac{\text { Control absorbance }- \text { Sample absorbance }}{\text { Control absorbance }} \times 100$

\subsection{Antimicrobial activity assay by dilution method}

\subsubsection{Antibacterial activity}

The Bauer-Kirby [36] disc diffusion experimental results of mm of maximum zone of inhibi- 
tion in millimeters were compared with the potency of all ketones in standard drugs against bacterial and fungal strains by measuring the minimum inhibitory concentration (MIC) of test compounds using the two-fold serial dilution method.

This procedure was applied for the seeded broth $\left(10^{-6}\right.$ to $\left.10^{-7} \mathrm{cfu} / \mathrm{ml}\right)$. Test samples were taken at different concentrations of 200, 100, 50, 25, 12.5, $6.25,3.13,1.56,0.78$, and $0.39 \mu \mathrm{g} / \mathrm{ml}$ to find the minimum inhibitory concentration (MIC) by using seeded broth as the diluent. Similarly, the standard solution of ampicillin drug was prepared at concentrations of $200,100,50,25.5,6.25,3.13,1.56,0.78$, and $0.39 \mu \mathrm{g} / \mathrm{ml}$ of sterile distilled water and dimethylsulfoxide (DMSO) was maintained throughout the experiment simultaneously as control.

The study involves a series of 10 assay tubes to investigate the effect of the test compounds against each strain. First, $1.6 \mathrm{ml}$ of seeded broth was transferred into the first assay tube and $0.4 \mathrm{ml}$ of the test solution was added and then mixed thoroughly to obtain a concentration of $200 \mu \mathrm{g} / \mathrm{ml}$. Next, $1 \mathrm{ml}$ of seeded broth was transferred into the remaining nine assay tubes and then $\mu \mathrm{g} / \mathrm{ml}$ of the content was pipetted out from the first assay tube and added to the second assay tube followed by thorough mixing. This type of dilution was repeated up to tenth assay tube serially. The same procedure was followed for standard drugs. Duplicates were also maintained under aseptic conditions.

The diluted samples of seeded broth tubes were kept in an incubator at $37 \pm 1{ }^{\circ} \mathrm{C}$ for $24 \mathrm{~h}$. After the incubation period, the concentrations of the assay tubes were altered using nutrient agar plates. The lowest concentration of the test samples gave good enough results for the complete inhibition of growth of the organism, which was taken as the minimum inhibitory concentration (MIC). The solvent control tube was simultaneously monitored for any inhibitory action. No inhibition was carried out for the sterile distilled water and dimethylsulfoxide (DMSO). The same procedure was employed for the measurement of antifungal activity of all compounds with their fungal strains.

In order to understand the results of the serial dilution method, the potency of synthesized compounds against the tested bacterial and fungal strains was calculated with respect to the reference (standards) using the following equation(1).

Potency $(\%)=\frac{\text { MIC }(\mu \mathrm{g} / \mathrm{ml}) \text { of reference compound }}{\text { MIC }(\mu \mathrm{g} / \mathrm{ml}) \text { of tested compound }} \times 100$

\section{RESULTS AND DISCUSSION}

In our synthetic organic chemistry research laboratory, the author has attempted to synthesize (4-bromo-1-naphthyl) (3-(substituted phenyl)bicyclo[2.2.1] heptene-2-yl)methanone derivatives by an environmentally benign water-mediated fly-ashcatalyzed Diels-Alder reaction with cyclopentadiene as diene and $(E)$-4-bromo-1-naphthyl chalcones as dienophiles. This reaction gave positive results. Fly-ash contains oxides of $\mathrm{Si}, \mathrm{Al}, \mathrm{Fe}, \mathrm{Ca}$ and organic muds as the main chemical components. The elemental analysis of lignite fly-ash (Class $\mathrm{C}$ fly-ash) indicates a composition of $15-45 \% \mathrm{SiO}_{2}$, 20-25\% $\mathrm{Al}_{2} \mathrm{O}_{3}, 6-15 \% \mathrm{Fe}_{2} \mathrm{O}_{3}, 15-40 \% \mathrm{CaO}$, and $0-5 \%$ C. During the reaction of diene and dienophiles, the chemical species present in the fly-ash catalyzed the [4+2] cycloaddition reaction. In this reaction, the obtained yield is more than $60 \%$. The electron-donating group substituted chalcones gave a yield of more than $65 \%$. The electronwithdrawing substituted chalcones gave a yield of $60 \%$. This reaction was useful for synthesizing the Diels-Alder adduct by adopting the waste pollutant as catalyst. Also, no yield was observed without fly-ash catalyst in the reaction. The analytical data, physical constants and microanalysis data are presented in Table 1 . The reusability of the catalyst in this reaction was studied in this cycloaddition with 2 mmol of 4-bromo-1-naphthylchalcone and 2 mmol of cyclopentadiene (compound 10) and is presented in Table 2. The first run gave a product yield of $65 \%$. The second and third runs gave 60 and $53 \%$, respectively. The fourth and fifth runs gave $40 \%$. The chalcone containing electrondonating substituents $\left(\mathrm{OCH}_{3}\right)$ gave a higher yield than electron-withdrawing (halogens and nitro) substituents. The effect of the catalyst on this reaction was studied by varying the catalyst quantity from 0.05 to $0.6 \mathrm{~g}$. As the catalyst quantity increased from 0.05 to $0.4 \mathrm{~g}$, the percentage of product increased from 58 to $65 \%$. On further increasing the catalyst amount beyond $0.4 \mathrm{~g}$, there was no increase in the percentage of product yielded. The effect of the catalyst loading is shown in Figure 1. The optimum quantity of catalyst loading was found to be $0.4 \mathrm{~g}$ of 4-bromo-1-naphthylchalcone substrate. The effect of solvents on this reaction (compound 10) was studied with the same quantity of reactants with methanol, dichloromethane, dioxane, and tetrahydrofuran and is presented in Table 3 . The higher yield was obtained in ethanol with fly-ash in water medium. 
Table 1

The physical constants and microanalysis data of (4-bromo-1-naphthyl)(3-(substituted phenyl) bicyclo[2.2.1]heptene-2-yl)methanone

\begin{tabular}{|c|c|c|c|c|c|c|c|c|}
\hline \multirow{2}{*}{ Cpd } & \multirow{2}{*}{$\mathrm{X}$} & \multirow{2}{*}{ M. F. } & \multirow{2}{*}{ MW } & \multirow[b]{2}{*}{ m.p. $\left({ }^{\circ} \mathrm{C}\right)$} & \multirow{2}{*}{ Yield (\%) } & \multicolumn{3}{|c|}{ Microanalysis (\%) } \\
\hline & & & & & & $\mathrm{C}$ & $\mathrm{H}$ & $\mathrm{N}$ \\
\hline 10 & $\mathrm{H}$ & $\mathrm{C}_{24} \mathrm{H}_{19} \mathrm{BrO}$ & 403 & $116-117$ & 65 & $\begin{array}{c}71.55 \\
(71.47)\end{array}$ & $\begin{array}{c}4.70 \\
(4.75)\end{array}$ & --- \\
\hline 11 & $3-\mathrm{NH}_{2}$ & $\mathrm{C}_{24} \mathrm{H}_{20} \mathrm{BrNO}$ & 418 & $79-80$ & 63 & $\begin{array}{c}68.95 \\
(68.91)\end{array}$ & $\begin{array}{c}4.79 \\
(4.82)\end{array}$ & $\begin{array}{c}3.30 \\
(3.35)\end{array}$ \\
\hline 12 & $3-\mathrm{Br}$ & $\mathrm{C}_{24} \mathrm{H}_{8} \mathrm{Br}_{2} \mathrm{O}$ & 482 & $112-113$ & 61 & $\begin{array}{c}59.72 \\
(59.78)\end{array}$ & $\begin{array}{c}3.71 \\
(3.76)\end{array}$ & - \\
\hline 13 & 4-Cl & $\mathrm{C}_{24} \mathrm{H}_{8} \mathrm{BrClO}$ & 437 & $114-115$ & 61 & $\begin{array}{c}65.84 \\
(65.85)\end{array}$ & $\begin{array}{l}4.07 \\
(4.14)\end{array}$ & - \\
\hline 14 & $4-\mathrm{N}\left(\mathrm{CH}_{3}\right)_{2}$ & $\mathrm{C}_{24} \mathrm{H}_{24} \mathrm{BrNO}$ & 445 & $122-123$ & 63 & $\begin{array}{c}69.95 \\
(69.96)\end{array}$ & $\begin{array}{c}5.39 \\
(5.42)\end{array}$ & $\begin{array}{c}3.14 \\
(3.19)\end{array}$ \\
\hline 15 & $4-\mathrm{OH}$ & $\mathrm{C}_{24} \mathrm{H}_{19} \mathrm{BrO}_{2}$ & 419 & $116-117$ & 62 & $\begin{array}{c}68.73 \\
(68.75)\end{array}$ & $\begin{array}{c}4.52 \\
(4.57)\end{array}$ & - \\
\hline 16 & $4-\mathrm{OCH}_{3}$ & $\mathrm{C}_{25} \mathrm{H}_{21} \mathrm{BrO}_{2}$ & 433 & $111-112$ & 65 & $\begin{array}{c}69.26 \\
(69.29)\end{array}$ & $\begin{array}{c}4.84 \\
(4.88)\end{array}$ & - \\
\hline 17 & $4-\mathrm{CH}_{3}$ & $\mathrm{C}_{25} \mathrm{H}_{21} \mathrm{BrO}$ & 417 & 103-104 & 64 & $\begin{array}{c}71.93 \\
(71.95)\end{array}$ & $\begin{array}{c}5.02 \\
(5.07)\end{array}$ & - \\
\hline 18 & $4-\mathrm{NO}_{2}$ & $\mathrm{C}_{24} \mathrm{H}_{18} \mathrm{BrNO}_{3}$ & 448 & $117-118$ & 61 & $\begin{array}{c}64.27 \\
(64.30)\end{array}$ & $\begin{array}{c}3.99 \\
(4.05)\end{array}$ & $\begin{array}{c}3.10 \\
(3.12)\end{array}$ \\
\hline
\end{tabular}

Values in the parentheses are calculated

T a ble 2

The effect of reuse of the catalyst on the yield of the aqueous phase Diels-Alder reaction of styryl 4-bromo-1-naphthyl ketone and cyclopentadiene (compound 10)

\begin{tabular}{cccccc}
\hline \hline Run & 1 & 2 & 3 & 4 & 5 \\
\hline Yield (\%) & 65 & 60 & 53 & 40 & 40 \\
\hline \hline
\end{tabular}

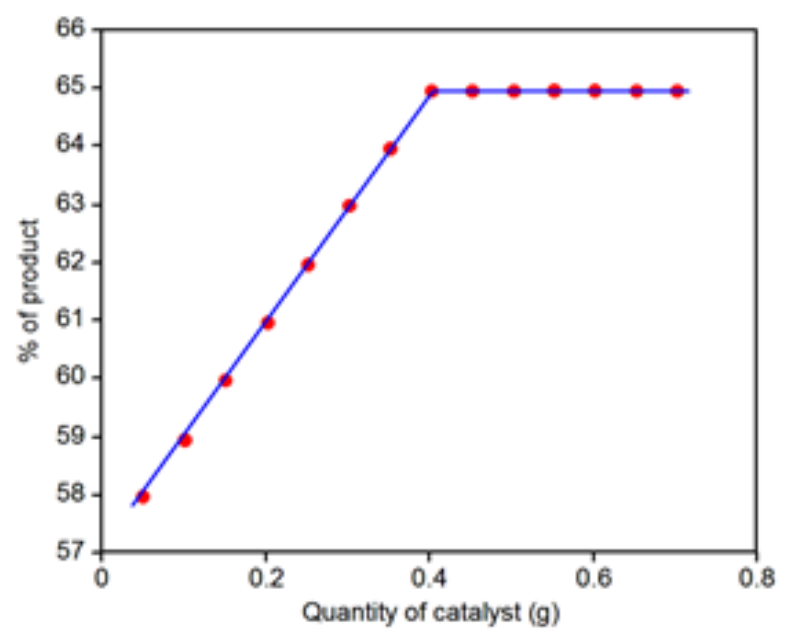

Fig. 1. The effect of catalyst loading

Table 3

The effect of solvents on the aqueous phase Diels-Alder reaction of styryl 4-bromo-1-naphthyl ketone and cyclopentadiene (compound 10)

\begin{tabular}{cccccc}
\hline \hline Solvent & Ethanol & Methanol & Dichloromethane & Dioxane & Tetrahydro furan \\
\hline Yield $(\%)$ & 65 & 63 & 62 & 60 & 62 \\
\hline \hline
\end{tabular}


In this experiment, the obtained products exist as single enantiomers. The synthesized ketones were characterized by their analytical data, physical constants (Table 1), and spectroscopic data, as follows. Based on earlier reports [1, 3, 4, 9, 21-25], the norbornyl ring exists as $1 S, 2 S, 3 S$, and $4 R$ geometries. The chemical shift $(\delta$, ppm) of the $\mathrm{C}-1$ proton is found to be around 3.75 as a double doublet. The chemical shift $(\delta, \mathrm{ppm})$ of the $\mathrm{C}-2$ proton is around 3.55 as triplets. The chemical shift $(\delta, \mathrm{ppm})$ of the $\mathrm{C}-3$ proton is around 3.4 as triplets. The chemical shift $(\delta, \mathrm{ppm})$ of the $\mathrm{C}-4$ proton is around 2.6 as double doublets. The chemical shift $(\delta, \mathrm{ppm})$ of $\mathrm{C}-5$ and $\mathrm{C}-6$ protons is around 6.5 as doublets. The chemical shifts $(\delta, \mathrm{ppm})$ of $\mathrm{C}-7$ and $\mathrm{C}-7^{\prime}$ protons are around the ranges of 1.8 and 1.6 as a doublet of doublets. The spectroscopic data of the synthesized Diels-Alder adducts are summarized below.

(4-Bromonaphthalen-1-yl)((1S,2S,3S,4R)-3-phenylbicyclo[2.2.1]hept-5-en-2-yl)methanone (10). IR $\left(\mathrm{KBr}, \mathrm{cm}^{-1}\right): v 3069,2885,1687,1514,1344$, 1172, 1082, 993, 711, 690, 585, 484; ${ }^{1} \mathrm{H}$ NMR (400 $\left.\mathrm{MHz}, \mathrm{CDCl}_{3}, \mathrm{ppm}\right): \delta 3.738\left(\mathrm{dd}, 1 \mathrm{H}, \mathrm{H}_{1,4}, J=6.4\right.$ and $4.0 \mathrm{~Hz}), 3.510\left(\mathrm{t}, 1 \mathrm{H}, \mathrm{H}_{2}, J=16 \mathrm{~Hz}\right), 3.481(\mathrm{t}$, $\left.1 \mathrm{H}, \mathrm{H}_{3}, J=17 \mathrm{~Hz}\right), 2.635\left(\mathrm{dd}, 1 \mathrm{H}, \mathrm{H}_{4}, J=4.0\right.$ and $4.8 \mathrm{~Hz}), 6.572\left(\mathrm{~d}, 1 \mathrm{H}, \mathrm{H}_{5,6}, J=16.5 \mathrm{~Hz}\right), 1.845(\mathrm{dd}$, $1 \mathrm{H}, \mathrm{H}_{7}, J=8.0$ and $\left.6.0 \mathrm{~Hz}\right), 1.612\left(\mathrm{dd}, 1 \mathrm{H}, \mathrm{H}_{7^{\prime}}, J=6\right.$ and $4 \mathrm{~Hz}), 7.176-8.917(\mathrm{~m}, 11 \mathrm{H}, \mathrm{Ar}-\mathrm{H}) ;{ }^{13} \mathrm{C}$ NMR (100 MHz, $\left.\mathrm{CDCl}_{3}, \mathrm{ppm}\right): \delta 196.37(\mathrm{CO}), 47.12$ $\left(\mathrm{C}_{1,4}\right), 53.81\left(\mathrm{C}_{2}\right), 45.07\left(\mathrm{C}_{3}\right), 134.43\left(\mathrm{C}_{6}\right), 136.17$ $\left(\mathrm{C}_{6}\right), 46.37\left(\mathrm{C}_{7}\right), 124.37-147.81(\mathrm{Ar}-\mathrm{C})$; $\mathrm{MS}(\mathrm{EI})$ : $\mathrm{m} / \mathrm{z} 403\left[\mathrm{M}^{+}\right], 405\left[\mathrm{M}^{2+}\right], 325,246,232,204,197$, 169, 154, 126, 92, 77, 28.

((1S, 2S, 3S, 4R)-3-(3-Aminophenyl)bicyclo [2.2.1] hept-5-en-2-yl)(4-bromonaphthalen-1-yl)methanone (11). IR $\left(\mathrm{KBr}, \mathrm{cm}^{-1}\right): v$ 3427, 3086, 2918, 1662, 1593, 1525, 1442, 1357, 1300, 1168, 1039, 837, 734, 466; ${ }^{1} \mathrm{H}$ NMR (400 MHz, $\mathrm{CDCl}_{3}, \mathrm{ppm}$ ): $\delta$ $3.754\left(\mathrm{dd}, 1 \mathrm{H}, \mathrm{H}_{1}, J=6.8\right.$ and $\left.4.0 \mathrm{~Hz}\right), 3.481(\mathrm{t}, 1 \mathrm{H}$, $\left.\mathrm{H}_{2}, J=16 \mathrm{~Hz}\right), 3.407\left(\mathrm{t}, 1 \mathrm{H}, \mathrm{H}_{3}, J=17 \mathrm{~Hz}\right), 2.655$ $\left(\mathrm{dd}, 1 \mathrm{H}, \mathrm{H}_{4}, J=4.0\right.$ and $\left.6.0 \mathrm{~Hz}\right), 6.417(\mathrm{~d}, 1 \mathrm{H}$, $\left.\mathrm{H}_{5,6}, J=16.5 \mathrm{~Hz}\right), 1.759\left(\mathrm{dd}, 1 \mathrm{H}, \mathrm{H}_{7}, J=8\right.$ and 6 $\mathrm{Hz}), 1.636\left(\mathrm{dd}, 1 \mathrm{H}, \mathrm{H}_{7^{\prime}}, J=6.4\right.$ and $\left.4.0 \mathrm{~Hz}\right), 6.317$ (s, 2H, $\left.\mathrm{NH}_{2}\right), 6.653-9.173(\mathrm{~m}, 10 \mathrm{H}, \mathrm{Ar}-\mathrm{H}) ;{ }^{13} \mathrm{C}$ NMR (100 MHz, $\left.\mathrm{CDCl}_{3}, \mathrm{ppm}\right): \delta 197.28(\mathrm{CO})$, $46.83\left(\mathrm{C}_{1,4}\right), 53.85\left(\mathrm{C}_{2}\right), 45.77\left(\mathrm{C}_{3}\right), 134.26\left(\mathrm{C}_{6}\right)$, $136.19\left(\mathrm{C}_{6}\right), 45.32\left(\mathrm{C}_{7}\right), 113.17-149.76(\mathrm{Ar}-\mathrm{C})$; MS (EI): $m / z 418\left[\mathrm{M}^{+}\right], 420\left[\mathrm{M}^{2+}\right], 401,391,325$, 232, 246, 204, 154, 92, 91, 77, 26, 16.

(4-Bromonaphthalen-1-yl)((1S,2S,3S,4R)-3-(3bromophenyl)bicyclo[2.2.1] hept-5-en-2-yl)methanone (12). IR $\left(\mathrm{KBr}, \mathrm{cm}^{-1}\right): v 3082,2916,1664$, 1593, 1521, 1442, 1359, 1168, 1041, 831, 732,
470; ${ }^{1} \mathrm{H}$ NMR (400 MHz, $\mathrm{CDCl}_{3}, \mathrm{ppm}$ ): $\delta 3.716$ $\left(\mathrm{dd}, 1 \mathrm{H}, \mathrm{H}_{1}, J=6.4\right.$ and $\left.4.0 \mathrm{~Hz}\right), 3.521\left(\mathrm{t}, 1 \mathrm{H}, \mathrm{H}_{2}, J\right.$ $=15.5 \mathrm{~Hz}), 3.443\left(\mathrm{t}, 1 \mathrm{H}, \mathrm{H}_{3}, J=17 \mathrm{~Hz}\right), 2.729(\mathrm{dd}$, $1 \mathrm{H}, \mathrm{H}_{4}, J=5.2$ and $\left.6.4 \mathrm{~Hz}\right), 6.481\left(\mathrm{~d}, 1 \mathrm{H}, \mathrm{H}_{5,6}, J=\right.$ $17 \mathrm{~Hz}), 1.812\left(\mathrm{dd}, 1 \mathrm{H}, \mathrm{H}_{7}, J=6.4\right.$ and $6.0 \mathrm{~Hz}$ ), $1.640\left(\mathrm{dd}, 1 \mathrm{H}, \mathrm{H}_{7^{\prime}}, J=8.0\right.$ and $\left.6.4 \mathrm{~Hz}\right), 7.217-$ $9.071(\mathrm{~m}, 10 \mathrm{H}, \mathrm{Ar}-\mathrm{H}) ;{ }^{13} \mathrm{C}$ NMR $(100 \mathrm{MHz}$, $\left.\mathrm{CDCl}_{3}, \mathrm{ppm}\right): \delta 198.32(\mathrm{CO}), 47.12\left(\mathrm{C}_{1,4}\right), 53.21$ $\left(\mathrm{C}_{2}\right), 44.68\left(\mathrm{C}_{3}\right), 135.27\left(\mathrm{C}_{6}\right), 136.14\left(\mathrm{C}_{6}\right), 46.11$ $\left(\mathrm{C}_{7}\right), 126.31-149.71$ (Ar-C); MS (EI): $\mathrm{m} / \mathrm{z} 482$ $\left[\mathrm{M}^{+}\right], 484\left[\mathrm{M}^{2+}\right], 486\left[\mathrm{M}^{4+}\right], 402,325,322,275$, 247, 232, 204, 196, 154, 126, 120, 92, 79, 77, 28.

\section{(4-Bromonaphthalen-1-yl)((1S,2S,3S,4R)-3-(4-} chlorophenyl)bicyclo[2.2.1]hept-5-en-2-yl)methanone (13). IR $\left(\mathrm{KBr}, \mathrm{cm}^{-1}\right)$ : v 3020, 2924, 1638, 1479, 1330, 1174, 1078, 997, 815, 804, 601, 489; ${ }^{1} \mathrm{H}$ NMR (400 MHz, $\left.\mathrm{CDCl}_{3}, \mathrm{ppm}\right): \delta 3.727(\mathrm{dd}, 1 \mathrm{H}$, $\mathrm{H}_{1}, J=4.0$ and $\left.6.4 \mathrm{~Hz}\right), 3.571\left(\mathrm{t}, 1 \mathrm{H}, \mathrm{H}_{2}, J=15\right.$ $\mathrm{Hz}), 3.461\left(\mathrm{t}, 1 \mathrm{H}, \mathrm{H}_{3}, J=17 \mathrm{~Hz}\right), 2.762(\mathrm{dd}, 1 \mathrm{H}$, $\mathrm{H}_{4}, J=4.0$ and $\left.6.4 \mathrm{~Hz}\right), 6.617\left(\mathrm{~d}, 1 \mathrm{H}, \mathrm{H}_{5,6}, J=17\right.$ $\mathrm{Hz}), 1.769\left(\mathrm{dd}, 1 \mathrm{H}, \mathrm{H}_{7}, J=6.0\right.$ and $\left.4.0 \mathrm{~Hz}\right), 1.684$ (dd, $1 \mathrm{H}, \mathrm{H}_{7^{\prime}}, J=6.0$ and $\left.4.0 \mathrm{~Hz}\right), 7.271-9.371$ (m, $10 \mathrm{H}, \mathrm{Ar}-\mathrm{H}) ;{ }^{13} \mathrm{C}$ NMR (100 MHz, $\left.\mathrm{CDCl}_{3}, \mathrm{ppm}\right): \delta$ $197.92(\mathrm{CO}), 46.73\left(\mathrm{C}_{1,4}\right), 53.24\left(\mathrm{C}_{2}\right), 45.73\left(\mathrm{C}_{3}\right)$, $134.28\left(\mathrm{C}_{6}\right), 136.27\left(\mathrm{C}_{6}\right), 46.34\left(\mathrm{C}_{7}\right), 126.72-145.72$ (Ar-C); MS (EI): $m / z 437\left[\mathrm{M}^{+}\right], 441\left[\mathrm{M}^{4+}\right], 420$ $\left[\mathrm{M}^{2+}\right], 402,357,325,323,204,126,120,111,92$, 89, 77, 35, 28.

(4-Bromonaphthalen-1-yl)((1S,2S,3S,4R)-3-(4-(dimethylamino)phenyl)bicyclo[2.2.1] hept-5-en-2-yl) methanone (14). IR $\left(\mathrm{KBr}, \mathrm{cm}^{-1}\right): v 2924,2864$, 1631, 1471, 1332, 1174, 1081, 997, 815, 707, 599, 491; ${ }^{1} \mathrm{H}$ NMR (400 MHz, $\left.\mathrm{CDCl}_{3}, \mathrm{ppm}\right): \delta$ $3.715\left(\mathrm{dd}, 1 \mathrm{H}, \mathrm{H}_{1}, J=6.4\right.$ and $\left.4.0 \mathrm{~Hz}\right), 3.441(\mathrm{t}$, $\left.1 \mathrm{H}, \mathrm{H}_{2}, J=16 \mathrm{~Hz}\right), 3.664\left(\mathrm{t}, 1 \mathrm{H}, \mathrm{H}_{3}, J=16.5 \mathrm{~Hz}\right.$ ), $2.499\left(\mathrm{dd}, 1 \mathrm{H}, \mathrm{H}_{4}, J=6.0\right.$ and $\left.4.8 \mathrm{~Hz}\right), 6.417(\mathrm{~d}$, $\left.1 \mathrm{H}, \mathrm{H}_{5,6}, J=16 \mathrm{~Hz}\right), 1.834$ (dd, $1 \mathrm{H}, \mathrm{H}_{7}, J=6.4$ and $4.0 \mathrm{~Hz}), 1.647\left(\mathrm{dd}, 1 \mathrm{H}, \mathrm{H}_{7}, J=6.0\right.$ and $\left.4.0 \mathrm{~Hz}\right)$, 3.178 (s, 3H, $\left.\mathrm{CH}_{3}\right), 7.172-9.301(\mathrm{~m}, 10 \mathrm{H}, \mathrm{Ar}-\mathrm{H})$; ${ }^{13} \mathrm{C}$ NMR (100 MHz, $\left.\mathrm{CDCl}_{3}, \mathrm{ppm}\right): \delta 196.73(\mathrm{CO})$, $46.92\left(\mathrm{C}_{1,4}\right), 53.14\left(\mathrm{C}_{2}\right), 44.94\left(\mathrm{C}_{3}\right), 135.71\left(\mathrm{C}_{6}\right)$, $136.28\left(\mathrm{C}_{6}\right), 46.32\left(\mathrm{C}_{7}\right), 45.32\left(\mathrm{CH}_{3}\right), 112.37-$ 149.37 (Ar-C); MS (EI): $m / z 445\left[\mathrm{M}^{+}\right], 447\left[\mathrm{M}^{2+}\right]$, 430, 401, 366, 325, 240, 232, 204, 126, 120, 92, 79, 77, 29, 15.

(4-Bromonaphthalen-1-yl)((1S,2S,3S,4R)-3-(4-hydroxyphenyl)bicyclo[2.2.1]hept-5-en-2-yl)methanone (15). IR $\left(\mathrm{KBr}, \mathrm{cm}^{-1}\right)$ : v 3433, 3020, 2922, 1639, 1487, 1336, 1172, 1078, 997, 813, 702, 597, 489; ${ }^{1} \mathrm{H}$ NMR (400 MHz, $\left.\mathrm{CDCl}_{3}, \mathrm{ppm}\right): \delta$ $3.709\left(\mathrm{dd}, 1 \mathrm{H}, \mathrm{H}_{1}, J=8.0\right.$ and $\left.4.0 \mathrm{~Hz}\right), 3.527(\mathrm{t}$, $\left.1 \mathrm{H}, \mathrm{H}_{2}, J=17 \mathrm{~Hz}\right), 3.592\left(\mathrm{t}, 1 \mathrm{H}, \mathrm{H}_{3}, J=16.5 \mathrm{~Hz}\right.$ ), $2.723\left(\mathrm{dd}, 1 \mathrm{H}, \mathrm{H}_{4}, J=6.4\right.$ and $\left.4.0 \mathrm{~Hz}\right), 6.371(\mathrm{~d}$, 
$\left.1 \mathrm{H}, \mathrm{H}_{5,6}, J=16.5 \mathrm{~Hz}\right), 1.796\left(\mathrm{dd}, 1 \mathrm{H}, \mathrm{H}_{7}, J=8.0\right.$ and $6.4 \mathrm{~Hz}), 1.628\left(\mathrm{dd}, 1 \mathrm{H}, \mathrm{H}_{7^{\prime}}, J=4.8\right.$ and 6.0 $\mathrm{Hz}), 5.714$ (s, 1H, OH), 6.671-8.927 (m, 10H, Ar$\mathrm{H}) ;{ }^{13} \mathrm{C}$ NMR $\left(100 \mathrm{MHz}, \mathrm{CDCl}_{3}, \mathrm{ppm}\right): \delta 197.22$ $(\mathrm{CO}), 46.63\left(\mathrm{C}_{1,4}\right), 53.61\left(\mathrm{C}_{2}\right), 45.73\left(\mathrm{C}_{3}\right), 135.26$ $\left(\mathrm{C}_{6}\right), 136.64\left(\mathrm{C}_{6}\right), 46.38\left(\mathrm{C}_{7}\right), 115.96-158.32(\mathrm{Ar}-$ C); MS (EI): $m / z 419\left[\mathrm{M}^{+}\right], 421\left[\mathrm{M}^{2+}\right], 401,325$, 246, 232, 213, 204, 185, 154, 126, 92, 77, 28.

(4-Bromonaphthalen-1-yl)((1S,2S,3S,4R)-3-(4-methoxyphenyl)bicyclo[2.2.1]hept-5-en-2-yl)methanone (16). IR $\left(\mathrm{KBr}, \mathrm{cm}^{-1}\right): v$ 3024, 2922, 1643, 1487, 1334, 1170, 1076, 997, 813, 702, 599, 489; ${ }^{1} \mathrm{H}$ NMR (400 MHz, $\left.\mathrm{CDCl}_{3}, \mathrm{ppm}\right): \delta 3.668(\mathrm{dd}$, $1 \mathrm{H}, \mathrm{H}_{1}, J=6.0$ and $\left.4.0 \mathrm{~Hz}\right), 3.492\left(\mathrm{t}, 1 \mathrm{H}, \mathrm{H}_{2}, J=16\right.$ $\mathrm{Hz}), 3.367\left(\mathrm{t}, 1 \mathrm{H}, \mathrm{H}_{3}, J=16 \mathrm{~Hz}\right), 2.744\left(\mathrm{dd}, 1 \mathrm{H}, \mathrm{H}_{4}\right.$, $J=6.0$ and $4.0 \mathrm{~Hz}), 6.470\left(\mathrm{~d}, 1 \mathrm{H}, \mathrm{H}_{5,6}, J=16 \mathrm{~Hz}\right)$, $1.823\left(\mathrm{dd}, 1 \mathrm{H}, \mathrm{H}_{7}, J=8.0\right.$ and $\left.6.4 \mathrm{~Hz}\right), 1.642(\mathrm{dd}$, $1 \mathrm{H}, \mathrm{H}_{7^{\prime}}, J=6.8$ and $\left.4.8 \mathrm{~Hz}\right), 3.932\left(\mathrm{~s}, 3 \mathrm{H}, \mathrm{OCH}_{3}\right)$, 6.857-9.091 (m, 10H, Ar-H); ${ }^{13} \mathrm{C}$ NMR (100 MHz, $\left.\mathrm{CDCl}_{3}, \mathrm{ppm}\right) \delta 196.24(\mathrm{CO}), 46.74\left(\mathrm{C}_{1,4}\right), 53.51\left(\mathrm{C}_{2}\right)$, $45.62\left(\mathrm{C}_{3}\right), 135.38\left(\mathrm{C}_{6}\right), 136.24\left(\mathrm{C}_{6}\right), 46.12\left(\mathrm{C}_{7}\right)$, $59.34\left(\mathrm{OCH}_{3}\right), 112.97-152.74(\mathrm{Ar}-\mathrm{C})$; MS (EI): $\mathrm{m} / \mathrm{z}$ $433\left[\mathrm{M}^{+}\right], 435\left[\mathrm{M}^{2+}\right], 417,353,325,277,232,204$, 126, 120, 107, 92, 91, 79, 28, 31, 15.

(4-Bromonaphthalen-1-yl)((1S,2S,3S,4R)-3-(4-methylphenyl)bicyclo[2.2.1]hept-5-en-2-yl)metha-

none(17). IR $\left(\mathrm{KBr}, \mathrm{cm}^{-1}\right): v 3035,2866,1683$, 1597, 1465, 1317, 1190, 1085, 999, 898, 694, 563, 482; ${ }^{1} \mathrm{H}$ NMR (400 MHz, $\mathrm{CDCl}_{3}, \mathrm{ppm}$ ): $\delta 3.755$ (dd, $1 \mathrm{H}, \mathrm{H}_{1}, J=6.4$ and $\left.4.0 \mathrm{~Hz}\right), 3.507\left(\mathrm{t}, 1 \mathrm{H}, \mathrm{H}_{2}, J\right.$ $=16.5 \mathrm{~Hz}), 3.417\left(\mathrm{t}, 1 \mathrm{H}, \mathrm{H}_{3}, J=17 \mathrm{~Hz}\right), 2.735(\mathrm{dd}$, $1 \mathrm{H}, \mathrm{H}_{4}, J=8.0$ and $\left.4.8 \mathrm{~Hz}\right), 6.451\left(\mathrm{~d}, 1 \mathrm{H}, \mathrm{H}_{5,6}, J=\right.$ $18 \mathrm{~Hz}), 1.797\left(\mathrm{dd}, 1 \mathrm{H}, \mathrm{H}_{7}, J=8.0\right.$ and $4.0 \mathrm{~Hz}$ ), $1.618\left(\mathrm{dd}, 1 \mathrm{H}, \mathrm{H}_{7^{\prime}}, J=6.4\right.$ and $\left.4.0 \mathrm{~Hz}\right), 2.417(\mathrm{~s}$, $\left.3 \mathrm{H}, \mathrm{CH}_{3}\right), 7.273-9.186(\mathrm{~m}, 10 \mathrm{H}, \mathrm{Ar}-\mathrm{H}) ;{ }^{13} \mathrm{C} \mathrm{NMR}$ $\left(100 \mathrm{MHz}, \mathrm{CDCl}_{3}, \mathrm{ppm}\right): \delta 197.38(\mathrm{CO}), 47.13$ $\left(\mathrm{C}_{1,4}\right), 53.17\left(\mathrm{C}_{2}\right), 45.36\left(\mathrm{C}_{3}\right), 135.26\left(\mathrm{C}_{6}\right), 136.74$ $\left(\mathrm{C}_{6}\right), 46.93\left(\mathrm{C}_{7}\right), 23.76\left(\mathrm{CH}_{3}\right), 125.98-140.22(\mathrm{Ar}-$ C); MS (EI): $m / z 417\left[\mathrm{M}^{+}\right], 419\left[\mathrm{M}^{2+}\right], 401,337$, 325, 233, 211, 204, 183, 126, 92, 91, 77, 28, 15.

(4-Bromonaphthalen-1-yl)((1S,2S,3S,4R)-3-(4-nitrophenyl)bicyclo[2.2.1] hept-5-en-2-yl)metha-

none (18). IR $\left(\mathrm{KBr}, \mathrm{cm}^{-1}\right): v$ 3072, 3030, 2877 , 1610, 1517, 1316, 1166, 1082, 989, 690, 569, 480; ${ }^{1} \mathrm{H}$ NMR (400 MHz, $\left.\mathrm{CDCl}_{3}, \mathrm{ppm}\right): \delta 3.771(\mathrm{dd}, 1 \mathrm{H}$, $\mathrm{H}_{1}, J=8.0$ and $\left.5.6 \mathrm{~Hz}\right), 3.534\left(\mathrm{t}, 1 \mathrm{H}, \mathrm{H}_{2}, J=16\right.$ $\mathrm{Hz}), 3.441\left(\mathrm{t}, 1 \mathrm{H}, \mathrm{H}_{3}, J=17 \mathrm{~Hz}\right), 2.762(\mathrm{dd}, 1 \mathrm{H}$, $\mathrm{H}_{4}, J=6.0$ and $\left.7.2 \mathrm{~Hz}\right), 6.420\left(\mathrm{~d}, 1 \mathrm{H}, \mathrm{H}_{5,6}, J=16.5\right.$ $\mathrm{Hz}), 1.791\left(\mathrm{dd}, 1 \mathrm{H}, \mathrm{H}_{7}, J=6.0\right.$ and $\left.8.0 \mathrm{~Hz}\right), 1.592$ (dd, $1 \mathrm{H}, \mathrm{H}_{7^{\prime}}, J=8.0$ and $\left.4.0 \mathrm{~Hz}\right), 7.631-9.140$ (m, $10 \mathrm{H}, \mathrm{Ar}-\mathrm{H}) ;{ }^{13} \mathrm{C}$ NMR $\left(100 \mathrm{MHz}, \mathrm{CDCl}_{3}, \mathrm{ppm}\right): \delta$ $198.64(\mathrm{CO}), 47.32\left(\mathrm{C}_{1,4}\right), 53.22\left(\mathrm{C}_{2}\right), 44.68\left(\mathrm{C}_{3}\right)$, $134.44\left(\mathrm{C}_{6}\right), 135.33\left(\mathrm{C}_{6}\right), 46.52\left(\mathrm{C}_{7}\right), 123.11-148.59$ (Ar-C); MS (EI): $m / z, 448\left[\mathrm{M}^{+}\right], 450\left[\mathrm{M}^{2+}\right], 401$, $368,325,242,232,214,205,154,126,122,92$, 91, 77, 46, 27.

\subsection{Antibacterial activity of ketones by disc diffusion method}

The disc diffusion technique was followed using the Bauer-Kirby [36] method at a concentration of $250 \mu \mathrm{g} \mathrm{ml}^{-1}$ with ampicillin used as the standard drug. The measured antibacterial activities of all methanones are presented in Table 4. The zone of inhibition in millimeters is shown in Figure 2. Methanones 3 and $\mathbf{4}$ showed excellent antibacterial activity against all bacterial strains.

Table 4

Antibacterial, antifungal and antioxidant activities of (4-bromo-1-naphthyl)-(3-(substituted phenyl) bicyclo[2.2.1]hept-5-en-2-yl)methanones

\begin{tabular}{|c|c|c|c|c|c|c|c|c|c|}
\hline \multirow{3}{*}{ Cpd } & \multirow{3}{*}{$\mathrm{X}$} & \multicolumn{5}{|c|}{ Antibacterial activity (zone of inhibition, $\mathrm{mm}$ ) } & \multirow{2}{*}{\multicolumn{2}{|c|}{$\begin{array}{c}\text { Antifungal activity } \\
\text { (zone of inhibition, } \\
\mathrm{mm} \text { ) }\end{array}$}} & \multirow{3}{*}{$\begin{array}{c}\text { Antioxidant } \\
\text { activity }\end{array}$} \\
\hline & & \multicolumn{3}{|c|}{ Gram-positive bacteria } & \multicolumn{2}{|c|}{ Gram-negative bacteria } & & & \\
\hline & & $\begin{array}{c}\text { B. } \\
\text { subtilis }\end{array}$ & $\begin{array}{c}\text { M. } \\
\text { luteus }\end{array}$ & $\begin{array}{c}S . \\
\text { aureus } \\
\end{array}$ & $\begin{array}{c}E . \\
\text { coli }\end{array}$ & $\begin{array}{c}P . \\
\text { aeruginosa } \\
\end{array}$ & $\begin{array}{c}\text { A. } \\
\text { niger }\end{array}$ & $\begin{array}{c}P . \\
s p p \\
\end{array}$ & \\
\hline 10 & $\mathrm{H}$ & 7 & 8 & 7 & 7 & 8 & 7 & 10 & $17.71 \pm 1.18$ \\
\hline 11 & $3-\mathrm{NH}_{2}$ & 8 & 7 & 7 & 7 & 8 & 7 & 10 & $14.53 \pm 1.94$ \\
\hline 12 & $3-\mathrm{Br}$ & 13 & 15 & 12 & 12 & 10 & 8 & 9 & $19.58 \pm 1.09$ \\
\hline 13 & $4-\mathrm{Cl}$ & 11 & 14 & 10 & 11 & 9 & 8 & 9 & $21.65 \pm 1.54$ \\
\hline 14 & $4-\mathrm{N}\left(\mathrm{CH}_{3}\right)_{2}$ & 7 & 7 & 7 & 6 & 7 & 10 & 9 & $21.45 \pm 1.64$ \\
\hline 15 & 4-OH & 6 & 6 & 8 & 7 & 7 & 7 & 7 & $37.95 \pm 1.24$ \\
\hline 16 & $4-\mathrm{OCH}_{3}$ & 8 & 6 & 7 & 7 & 8 & 7 & 9 & $35.56 \pm 1.65$ \\
\hline 17 & $4-\mathrm{CH}_{3}$ & 9 & 7 & 7 & 7 & 6 & 9 & 7 & $22.44 \pm 1.62$ \\
\hline 18 & $4-\mathrm{NO}_{2}$ & 6 & 7 & - & 6 & 7 & 12 & 12 & $11.04 \pm 1.82$ \\
\hline \multicolumn{2}{|c|}{ Ampicillin } & 16 & 19 & 14 & 17 & 13 & - & - & $39.14 \pm 1.57$ \\
\hline \multicolumn{2}{|c|}{ Miconazole } & - & - & - & - & - & 14 & 13 & $(\mathrm{DPPH})$ \\
\hline
\end{tabular}



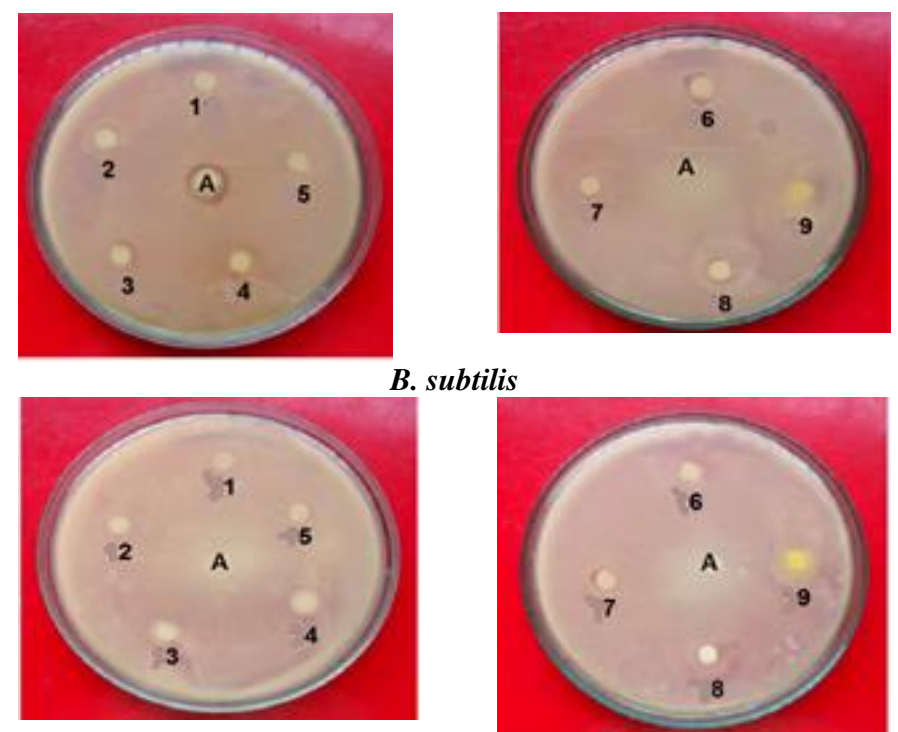

B. subtilis

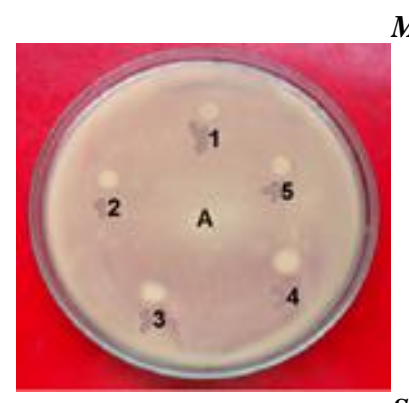

M. luteus
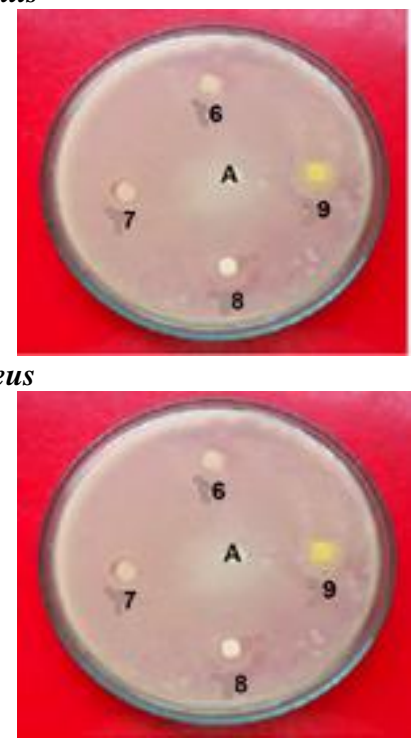

S. aureus
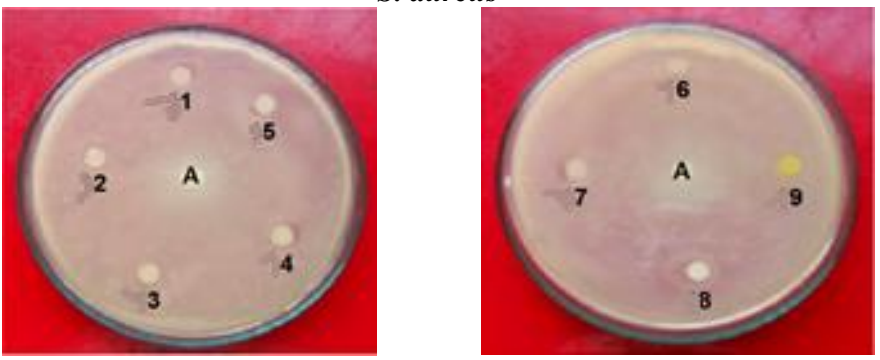

E.coli
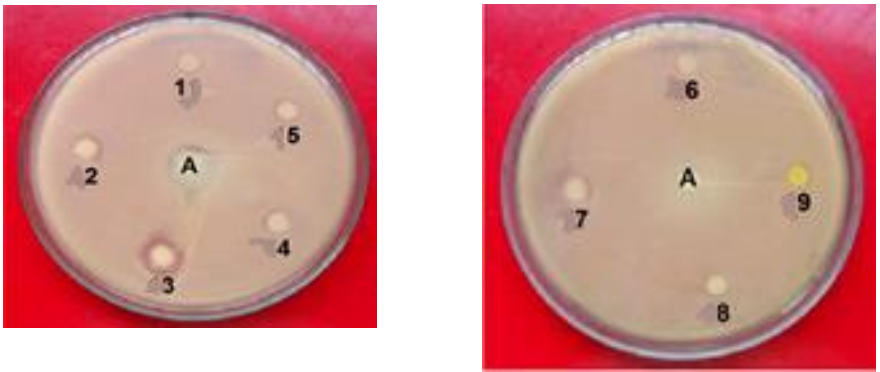

P.aeruginosa

Fig. 2. Antibacterial activity as millimeters of zone of inhibition of (4-bromo-1-naphthyl)-(3-(substituted phenyl)bicyclo[2.2.1]hept-5-en-2-yl)methanones

Compounds containing $\mathrm{H}-$, amino-, dimethylamino-, methoxy- and methyl-substitutions (1, 2, 5, 7 and 8) showed moderate antibacterial activity against Bacillus subtilis bacterial strains. The nitro- and hydroxy-substituted methanones (6 and 9) showed the least activity against $B$. subtilis bacterial strains. Compounds containing hydroxy and methoxy substituents (6 and 7) show poor antibacterial activity against the Micrococcus $l u$ teus bacterial strain. With regard to compound 9 , nitro substitution was inactive against $S$. aureus strain. Dimethylamino- and nitro-substituted methanones show poor antibacterial activity against E. coli strain. Methanone with methyl substitution (8) shows the least antibacterial activity against $P$. aeruginosa bacterial strain.

\subsection{Antifungal sensitivity assay of ketones by disc diffusion method}

The observed antifungal activities of all prepared bicyclic methanones are presented in Table 4 . The zones of inhibition of methanones with fungal strains in Petri plates are shown in Figure 3. The nitro-substituted compound methanone 9 showed excellent antifungal activity against Aspergillus niger and P. spp fungal strains. Dimethylamino- and methyl-substituted methanones (5 and 9) showed moderate activity against $A$. niger fungal strain. The parent- and amino-, hydroxy-, and methoxysubstituted compounds $(\mathbf{1}, \mathbf{2}, \mathbf{6}$, and $\mathbf{7})$ showed the least antifungal activity. The parent methanone and amino- and nitro-substituted compounds $(\mathbf{1}, \mathbf{2}$, and 9) showed excellent antifungal activity against $P$. spp fungal strain. Compounds containing halogensand dimethylamino- and methoxy-substitutions (35 and 7) showed good antifungal activities against Pen. spp fungal strain. Hydroxy- and methylsubstituted methanones (6 and 9) showed the least antifungal activity against $P e n . s p$ strain.
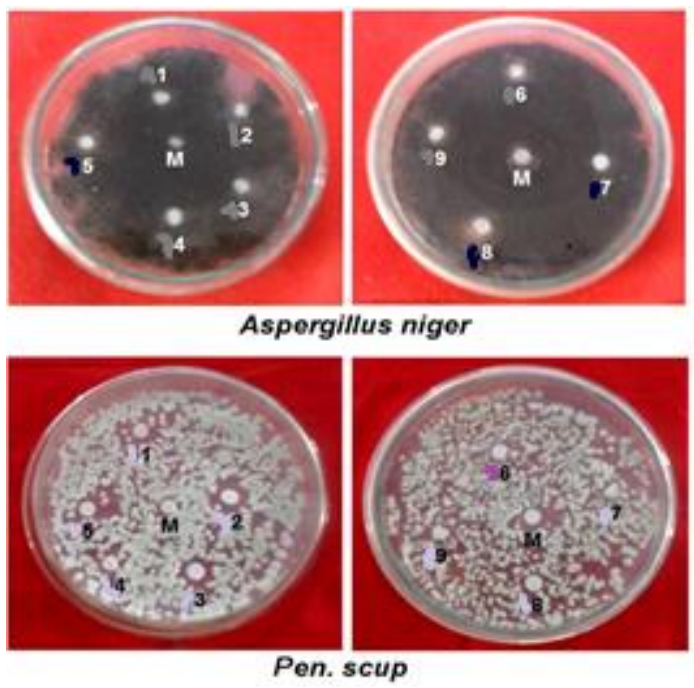

Fig. 3. Antifungal activity as millimeters of zone of inhibition of (4-bromo-1-naphthyl)-(3-(substituted phenyl)bicyclo[2.2.1]hept-5-en-2-yl)methanones 


\subsection{Antimicrobial activities by serial dilution method}

The antimicrobial assay of prepared methanones was measured by the serial dilution method. In this method, the minimum inhibitory concentration (MIC) values and the percentage potency of all compounds against the microbial strains were measured. For the dilution concentration of $1.5-0.3 \mu \mathrm{g} / \mathrm{ml}$, the observed statistical data are presented in Table 5 and the potency diagram is illustrated in Figure 4.

\subsubsection{Antibacterial activity}

From Table 5, methanone 4 shows the maximum potency (90\%) and compound 2 shows the minimum potency $(10 \%)$ against $B$. subtilis strain. The electron-withdrawing 4-chloro substituted methanone maximizes the potency, the electrondonating 4-methoxy substitution produces good activity, and the amino group reduces the potency to the minimum for $B$. subtilis. Ketone $\mathbf{3}$ shows maximum potency (92\%) and compounds 2 and $\mathbf{6}$ show minimum potencies (15\%) against $M$. luteus strain. The compounds $\mathbf{1}, \mathbf{4}$, and 5 show more than $50 \%$ antibacterial potency against this strain. The ketones 7-9 show less than 50\% potency against $M$. luteus strain. The bromo-substituted compound shows maximum MIC-potency values and the amino substitution shows the minimum MICpotency values against $M$. luteus strain. Methanones 3 and $\mathbf{4}$ show maximum (90\%) potencies against $S$. aureus bacterial strain. Compounds 1, 2 , and 7 show more than $50 \%$ potency and the ketones 5, 6, 8 and 9 show less than $50 \%$ potency against $S$. aureus strain. Here the electronwithdrawing 3-chloro, 3-bromo substituents were enhanced and 4-hydroxy and 2-nitro substituents reduced the antibacterial activities (30\%) against $S$. aureus strain. Methanone $\mathbf{4}$ showed more than $100 \%$ potency $(102 \%)$ and ketone 8 showed the lowest potency $(15 \%)$ of antibacterial activity against $E$. coli strain. These potencies correspond to the methanones containing the electronwithdrawing 4-chloro and electron-donating 4methyl substituents. The remaining methanones, 1-3, 5, 6 and 7, showed more than 50\% potency of antibacterial activity against $E$. coli strain. Ketone 4 showed maximum potency (95\%) against $P$. aeruginosa bacterial strain. This observation is attributed to the fact that the electron-withdrawing 4chloro substituent enhanced the maximum potency and the electron-donating 4-nitro substituent reduced the potency to less than $50 \%$. The compounds 1-3, 5-7 and $\mathbf{8}$ showed more than 50\% potency against $P$. aeruginosa bacterial strain.

\section{Table 5}

The antibacterial and antifungal activities of (4-bromo-1-naphthyl)-(3-(substituted phenyl) bicyclo[2.2.1]hept-5-en-2-yl)methanones by serial method

\begin{tabular}{|c|c|c|c|c|c|c|c|c|}
\hline \multirow{3}{*}{ Cpd } & \multirow{3}{*}{$\mathrm{X}$} & \multicolumn{5}{|c|}{ Antibacterial activity MIC-potency } & \multirow{2}{*}{\multicolumn{2}{|c|}{$\begin{array}{l}\text { Antifungal activity } \\
\text { MIC-potency }\end{array}$}} \\
\hline & & \multicolumn{3}{|c|}{ Gram-positive bacteria } & \multicolumn{2}{|c|}{ Gram-negative bacteria } & & \\
\hline & & B. subtilis & M. luteus & S. aureus & E. coli & P. aeruginosa & A. niger & P. spp. \\
\hline 10 & $\mathrm{H}$ & 60 & 70 & 55 & 71 & 65 & 80 & 75 \\
\hline 11 & $3-\mathrm{NH}_{2}$ & 10 & 15 & 60 & 63 & 55 & 85 & 90 \\
\hline 12 & $3-\mathrm{Br}$ & 75 & 92 & 90 & 95 & 80 & 65 & 80 \\
\hline 13 & $4-\mathrm{Cl}$ & 90 & 88 & 90 & 102 & 95 & 60 & 75 \\
\hline 14 & $4-\mathrm{N}\left(\mathrm{CH}_{3}\right)_{2}$ & 15 & 60 & 35 & 63 & 70 & 80 & 90 \\
\hline 15 & $4-\mathrm{OH}$ & 20 & 15 & 30 & 55 & 50 & 70 & 80 \\
\hline 16 & $4-\mathrm{OCH}_{3}$ & 40 & 30 & 85 & 90 & 65 & 85 & 90 \\
\hline 17 & $4-\mathrm{CH}_{3}$ & 35 & 20 & 40 & 15 & 80 & 90 & 95 \\
\hline 18 & $4-\mathrm{NO}_{2}$ & 38 & 25 & 30 & 40 & 45 & 95 & 95 \\
\hline & picillin & 18 & 18 & 18 & 18 & 18 & - & - \\
\hline & onazole & - & - & - & - & - & 15 & 15 \\
\hline
\end{tabular}

\subsubsection{Antifungal activity}

The prepared methanone 9 showed the maximum potency $(95 \%)$ and all other ketones showed more than $50 \%$ potency against $A$. niger fungal strain. The electron-withdrawing 4-methyl and 4nitro substituents enhanced the maximum antifun- gal potency against $A$. niger strain. The compounds $\mathbf{8}$ and $\mathbf{9}$ showed maximum potency $(95 \%)$ against Penicillium spp. fungal strain. All compounds showed more than $50 \%$ potency against Penicillium spp. strain. The electron-withdrawing nitrosubstituents and amino-substituents enhanced the maximum antifungal potency. 


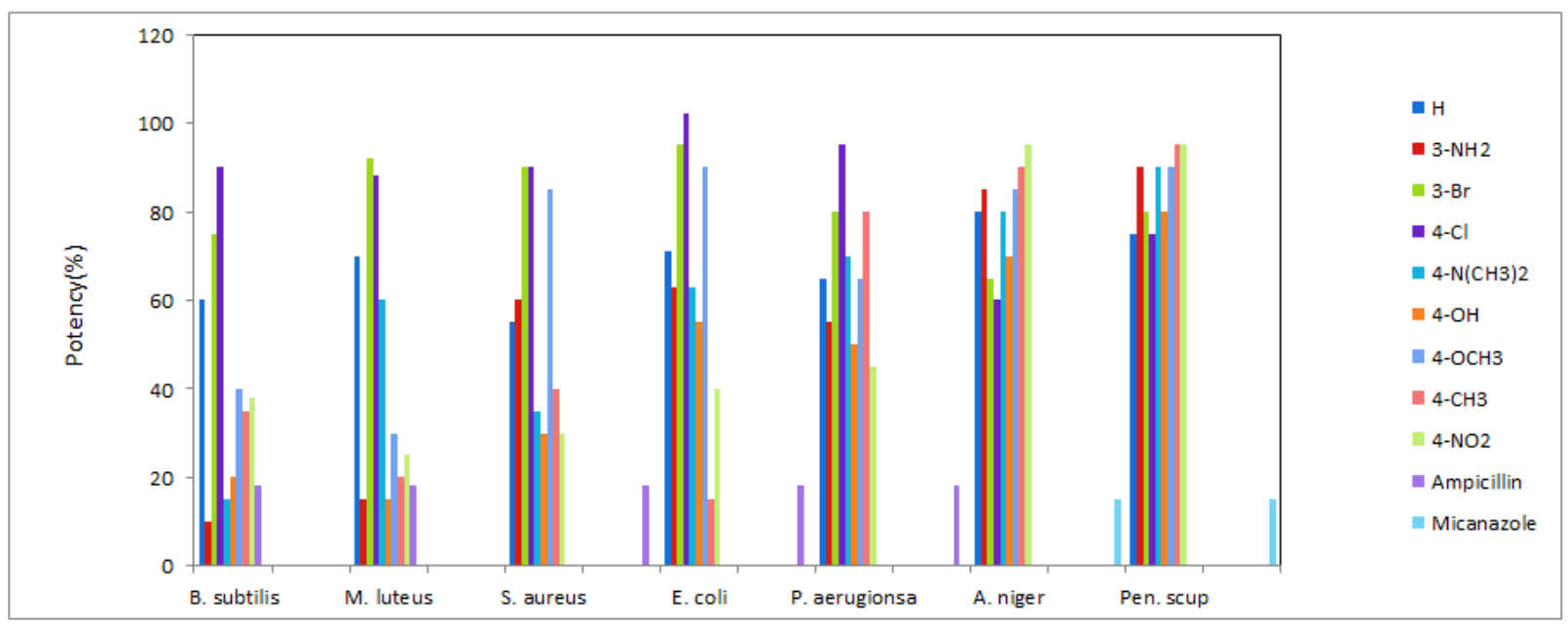

Fig. 4. Potency diagram of antibacterial and antifungal activities of (4-bromo-1-naphthyl)-(3-(substituted phenyl)bicyclo[2.2.1] hept-5-en-2-yl)methanones found by the serial method

\subsection{Antioxidant activity}

The antioxidant activities of synthesized (4bromo-1-naphthyl)-(3-(substituted phenyl)bicycle [2.2.1] hept-5-en-2-yl)methanones were measured using the diphenyl picryl hydrazyl (DPPH) radical scavenging method [35]. The observed antioxidant activities of methanones are presented in Table 4. From Table 4, it can be seen that the hydroxyl- and methoxy-substituted methanones (6 and 7) showed significant antioxidant activity.

\section{CONCLUSIONS}

Totally nine (4-bromo-1-naphthyl)(3-(substituted phenyl)bicyclo[2.2.1]hept-5-en-2-yl)methanones were synthesized by an environmentally benign water-mediated Diels-Alder [4+2] cycloaddition reaction between 4-bromo-1-naphthyl chalcones and cyclopentadiene under cooling conditions. The yields of the synthesized ketones were more than $60 \%$. The synthesized ketones were characterized by their physical constants and spectroscopic data. The antimicrobial activities of these synthesized ketones were studied by disc diffusion and the serial dilution method. From the disc diffusion technique, it was found that the methanol derivatives possessing halogens, dimethylamino, nitro, methyl, amino, and $\mathrm{H}$ substituents showed very good antibacterial activity. The nitro, amino, dimethylamino, parent and methoxy substituents present in methanones showed excellent, very good, and good antifungal activities against the fungal strains. From the serial dilution method, it was found that the electron-withdrawing bromo-, chloro- and nitro-substituted compounds showed max- imum antibacterial and antifungal potency against the bacterial and fungal strains.

Acknowledgment. The author gratefully acknowledges the University Grants Commission, New Delhi, India, for financial support under Grant No. F.30-23/2011(SA-II) through the UGC-PDF Research Award.

\section{REFERENCES}

[1] A. N. Thadani, A. R Stankovic, V. H. Rawal, Enantioselective CuII-catalyzed Diels-Alder and Michael addition reactions in water using bio-inspired triazacyclophanebased ligands, Eur. J. Org. Chem, 1714-1720 (2011). DOI: $10.1002 /$ ejoc. 201001522.

[2] H. B. Albada, F. Rosati, D. Cquiere, G. Rofelfes, R. M. J. Liskamp, Enantioselective Diels-Alder reactions catalyzed by hydrogen bonding, PNAS, 101, 5846-5850 (2004). DOI: 10.1073/pnas.0308545101.

[3] E. B. Mubofu, J. B. F. N. Engberts, Specific acid catalysis and Lewis acid catalysis of Diels-Alder reactions in aqueous media, J. Phys. Org. Chem, 17, 180-186 (2004). DOI: $10.1002 /$ poc.711.

[4] B. Liu, T.Y. Liu, S. W. Luo, L. Z.Gong, Asymmetric hetero Diels-Alder reaction of diazines catalyzed by chiral silver phosphate: Water participates in the catalysis and stereocontrol, Org Lett, 16, 6164-6167 (2014). DOI: dx.doi.org/ 10.1021/ ol503047s.

[5] D. B. Ramachary, N. S. Chowdari, C. F. Barbas, Aminecatalyzed direct self Diels-Alder reactions of $\alpha, \beta$ unsaturated ketones in water: Synthesis of pro-chiral cyclohexanones, Tetrahedron Lett. 43, 6743-6746 (2002). DOI: http://dx.doi.org/10.1016/S0040-4039 (02)01500-9.

[6] R. Thayumanavan, B. Dhevalapally, K. Sakthivel, F. Tanaka, C. F. Barbas, Amine-catalyzed direct DielsAlder reaction of $\alpha, \beta$-unsaturated ketones with nitro olefins, Tetrahedron Lett, 43, 3817-3820 (2002). DOI: http://dx.doi.org/10.1016/S0040-4039(02)00686-X

[7] M. Krebs, S. Laschat, Lewis acid catalyzed Diels-Alder reaction of 2-cyclopentenones with Danishfsky's diene: double bond isomerization of tetrahydro- $1 \mathrm{H}$-indene- 
1,5(7aH)-diones, and attempts on an asymmetric catalysis, Arkivoc, 3, 5-19 (2012).

[8] V. Marchan, S. Ortega, D. Pulido, E. Pedroso, A. Grandas, Diels-Alder cycloadditions in water for the straightforward preparation of peptide-oligonucleotide conjugates, Nucleic Acids Res, 34, e24 (2006). DOI:10.1093/nar/gnj020

[9] P. Buonora, J. C. Olsen, T. Oh, Recent developments in imino Diels-Alder reactions, Tetrahedron. 57, 60996138 (2001) DOI: http://dx.doi.org/10.1016/S0040-4020 (01) 00438-0

[10] P. A. Grieco, J. J. Nunes, M. D. Gaul, Dramatic Rate Accelerations of Diels-Alder Reactions in $5 \mathrm{M}$ Lithium Perchlorate-Diethyl Ether: The Cantharidin Problem Reexamined, J Am Chem Soc, 112, 4595-4596 (1990). DOI: $10.1021 /$ ja00167 a096.

[11] K. T. Gagnon, S. Y. Ju, M. B. Goshe, E. S. Maxwell, S. Franzen, A role for hydrophobicity in a Diels-Alder reaction catalyzed by pyridyl-modified RNA, Nucleic Acids Res, 37, 3074-3082 (2009). DOI: 10.1093/nar/gkp177.

[12] M. B. Gawande, Current Trends in Aqueous Mediated Organic Synthesis. Organic Chem Curr Res, 3, 100e134, (2014).

DOI: http://dx.doi.org/10.4172/2161-0401.1000e134.

[13] J. Bah, J. Franzén, Carbocations as Lewis Acid Catalysts in Diels-Alder and Michael Addition Reactions, ChemEur J, 20, 1066-1082 (2014). DOI: $10.1002 /$ chem. 201304160

[14] F. A. Gbaguidi, U. C. Kasséhin, J. R. C. Prevost, R. Frederick, C. R. McCurdy, J. H. Poupaert, Insight into the Diels-Alder reaction: A green chemistry revisitation of the synthesis of a cantharidine-like trypanocidal pilotmolecule, J. Chem. Pharm. Res, 7, 1109-1113 (2015).

[15] L. C. Dias, Chiral Lewis acid catalysts in Diels-Alder cycloadditons: Mechanistic aspects and synthetic applications of recent systems, J. Braz. Chem. Soc, 8, 289232 (1997).

DOI:http://dx.doi.org/10.1590/S0103-50531997000400001

[16] N. A. Mirgane, A. V. Karnik, Aqueous ethanol: a suitable medium for the diastereoselective Diels-Alder reaction mediated by chiral bases, Green Chem. Lett. Rev, 4, 269-272 (2011).

DOI: http://dx.doi.org/10.1080/17518253.2011.571715

[17] D. H. Paull, E. A. Danforth, J. Wolfer, C. D. Isonagie, C. J. Abraham, T. J. Lectka, An Asymmetric, bifunctional catalytic approach to non-natural alpha-amino acid derivatives, Org. Chem, 72, 5380-5382 (2007). DOI: $10.1021 /$ jo070472x

[18] Larson C H M, Ph.D. Thesis, California Institute of Technology, 2005.

[19] K. E. Litz, Aqueous Ti(IV)-Catalyzed Diels-Alder Reaction., Molecules, 12, 1674-1678 (2007). DOI: $10.3390 / 12081674$

[20] C. Loncaric, K. Manabe, S. Kobayashi, Alkaline saltcatalyzed aza Diels-Alder reactions of Danishefsky's diene with imines in water under neutral conditions, Chem. Communn, 574-676 (2003). DOI: 10.1039/B300880K, Communication

[21] G.Thirunarayanan, Insect antifeedant potent $9 H$ fluorenacyl bromide, $Q$-Science Connect, 2014. DOI: http://dx.doi.org/ 10.5339/ connect. 2014.18
[22] G. Thirunarayanan, Aqueous phase fly-ash catalyzed [4+2] Diels-Alder reaction of aryl enones and cyclopentadiene: Synthesis and insect antifeedant activities of arylbicyclo[2.2.1] heptene-2-yl-methanones, Annales-UMCS, 9, 127-140 (2014).

DOI: http://dx.doi.org/10.17951/aa.2014.69.1-2.127

[23] G. Thirunarayanan, Synthesis of antimicrobial, antioxidant and insect antifeedant potent 3,4-dimethyl phenyl bicyclo[2.2.1]heptane methanone derivatives, Org. Chem: An Indian J., 13, 112-121 (2015).

[24] G. Thirunarayanan, Bio-potent (5-chloro-2-thienyl)-3(substituted phenyl) bicyclo[2.2.1] heptane-2-yl methanone derivatives, Int. Lett. Chem. Phys. Astro, 42, 1-12 (2015).

[25] G. Thirunarayanan, Synthesis, pharmacological and insect antifeedant activity evolution of some (4-chloro1-naphthyl)(3-(substituted phenyl) bicyclo[2.2.1]hept-5en-2-yl) methanones, Int. J. Chem, 4, 173-182 (2015).

[26] I. H. Chen, J. N. Young, S. J. Yu, Recyclable organotungsten Lewis acid and microwave assisted DielsAlder reactions in water and in ionic liquids, Tetrahedro, 60, 11903-11909 (2004). DOI: http://dx.doi.org/10.1016/j.tet.2004.09.078.

[27] A. Serganow, S. Keiper, L. Malinina, V. Tereshko, E. Skripkin, C. Hobartner, A. Polonskaia, A. T. Phan, R. Wombacher, R. Micura, Z. Dauter, A. Jaschke, D. J. Patel, Structural basis for Diels-Alder ribozyme-catalyzed carbon-carbon bond formation, Nature Struct. Mol. Biol, 12, 218-224 (2005). DOI: 10.1038/nsmb906

[28] Rer Nat, Disseration, Universitat Regensburg. 2009.

[29] A. Wittkopp, P. R. Schreiner, Metal-Free, Noncovalent Catalysis of Diels \pm Alder Reactions by Neutral Hydrogen Bond Donors in Organic Solvents and in Water, Chem. Eur. J. 9, 407-414 (2003). DOI: $10.1002 /$ chem.200390042.

[30] T. S. Fard, S. Caratzoulas, D. J. Doren, DFT study of solvent effects in acid-catalyzed Diels-Alder cycloadditions of 2,5-dimethylfuron and maleic anhydride, $J$. Phys. Chem, 119, 9834-9843 (2015). DOI: $10.1021 /$ acs. jpca.5b05060.

[31] B. Yang, P. A. Miller, U. Möllmann, M. J. Miller, Syntheses and Biological Activity Studies of Novel Sterol Analogs from Nitroso Diels-Alder Reactions of Ergosterol, Org. Lett, 11, 2828-2831 (2009). DOI: $10.1021 / \mathrm{ol} 900997 \mathrm{t}$.

[32] C.T. Qian, L. C. Wang, R. F. Chen, Asymmetric Hetero Diels-Alder Reaction of Chiral Imines with Danishefsky's Diene Catalyzed by $\mathrm{Yb}(\mathrm{OTf})_{3}$, Chinese J. Chem, 19, 419-422 (2001). DOI: 10.1002/cjoc.20010190418.

[33] Z. P. Pai, P. V. Berdnikova, A. A. Nosikov and B. M. Khlebnikov, Catalytic Oxidation of $\alpha, \beta$ - and $\beta, \gamma-$ Unsaturated Bicyclic Ketones by Hydrogen Peroxide, Chem. Sus. Dev, 16, 413-418, (2008).

[34] R. Pratap, R. Raghunathan, A. Kumar, V. J. Ram, Bicyclic ketone mediated synthesis of oxygenated aromatic systems, RSC Adv, 2, 2688-2691 (2012). DOI: 10.1039/ C2RA01253G, Communication.

[35] G. Thirunarayanan, Antimicrobial and antioxidant potent 2(5-bromo-2-thienyl)-3-(substituted phenyl) bicyclo[2.2.1] heptane-5-ene-2-ylmethanone derivatives, Chem. J. 6, 4148 (2016). 
[36] G. Thirunarayanan, Synthesis, characterization and evaluation of biological activities of some 2,3-diaryl bicyclo methanones. Ovidius Univ. Annals Chem, 27, 36-42 (2016). DOI: 10.1515/auoc-2016-0003.

[37] G. Thirunarayanan, Greener Synthesis, antimicrobial, antioxidant and insect antifeedant activities of some 2(9-anthryl)-3-(substituted phenyl)bicyclo[2.2.1]hept-5ene-2-yl ketones J Pharm Appl Chem, 2, 59-66 (2016). DOI: http://dx.doi.org /10.18576/jpac/pape

[38] W. Dehaen, A. A. Mashentseva,T. S. Seitembetov, Allobetulin and Its Derivatives: Synthesis and Biological Activity, Molecules, 16, 2443-2466 (2011). DOI: $10.3390 /$ molecules 16032443.

[39] A. S. Saratikov, L. A. Pchelkina, N. A. Belikova, A. A. Boyleva, N. F. Dubitskaya, M. D. Ordubadi, S. K. Ermolaeva, A. F. Plate, Biological activity of bi and tri cyclic ketones., Khim. Farm. Zhurnal, 11, 59-61 (1977).
[40] D. Belsito, D. Bickers, M. Bruze, P. Calow, M. L. Dagli, A. D. Fryer, H. Greim, Y. Miyachi, J. H. Saurat, I. G. Sipes, A toxicological and dermatological assessment of alkyl cyclic ketones when used as fragrance ingredients The RIFM Expert Panel., Food Chem. Toxicol, 62, S1-S44 (2013). DOI: http://dx.doi.org/10.1016/ j.fct. 2013. 09.033.

[41] F. D. Pop, R. Parson, B. E. Donigan, Potential anticonvulsants.III. The condensation of isatin with cyclic ketones. J. Heterocyclic Chem, 17, 1329-1330 (1980). DOI: 10.1002/jhet.5570170639

[42] A. W. Bauer, W. M. M. Kirby, J. C. Sherris, M. Truck, Antibiotic susceptibility testing by a standardized single disk method, Am. J. Clin. Pathol, 45, 493-496 (1966). DOI: https://www.ncbi.nlm.nih.gov/pubmed/5325707

[43] G. Thirunarayanan, G. Vanangamudi, Synthesis of some 4-bromo-1-naphthyl chalcones using silica-sulfuric acid reagent under solvent free conditions, Arkivoc, 12, 58-64 (2006). 